\title{
Activation of a Nonselective Cationic Conductance by Metabotropic Glutamatergic and Muscarinic Agonists in CA3 Pyramidal Neurons of the Rat Hippocampus
}

\author{
Nathalie C. Guérineau, Jean-Louis Bossu, Beat H. Gähwiler, and Urs Gerber \\ Brain Research Institute, University of Zurich, $\mathrm{CH}-8029$ Zurich, Switzerland
}

We have characterized a cationic membrane conductance activated by metabotropic glutamatergic and muscarinic cholinergic agonists in CA3 neurons in hippocampal slice cultures using the patch-clamp technique. When the potassium concentration in the superfusing fluid was raised above $5 \mathrm{~mm}$, a biphasic current was observed in cells held at $-60 \mathrm{mV}$ in response to stimulation of postsynaptic metabotropic glutamate receptors (mGluRs) with 1S,3R-ACPD $(50 \mu \mathrm{M})$ or muscarinic receptors with methacholine (MCh, $5 \mu \mathrm{M})$. The initial inward component was due to an increase in a cationic membrane conductance as determined by its reversal potential and its sensitivity to changes in extracellular $\mathrm{K}^{+}$or $\mathrm{Na}^{+}$. The conductance underlying this current displayed no apparent voltage sensitivity over the range -120 to $-50 \mathrm{mV}$. The response was reduced by extracelIular application of $\mathrm{Ba}^{2+}, \mathrm{Cd}^{2+}, \mathrm{Mg}^{2+}$, or TEA, whereas extracellular $\mathrm{Cs}^{+}$or loading cells with BAPTA or $\mathrm{Cs}^{+}$did not affect the current. The effects of $1 S, 3 R$-ACPD were reversibly inhibited by bath-applied MCPG, an antagonist at mGluRs. Experiments with atropine and pirenzepine indicated that non- $M_{1}$ muscarinic receptors mediated the $\mathrm{MCh}$ induced current. A decrease in a resting leak potassium conductance $\left(l_{\mathrm{K} \text {,leak }}\right)$ was responsible for the late component of the 1S,3R-ACPD- and MCh-induced response, seen as an outward current in the bathing solution with high $\mathrm{K}^{+}$ concentration. Loading cells with GDP $\beta S$, GTP $\gamma$ S, or GTP did not alter the cationic current, while, in the same cells, the reduction in $I_{k \text {, leak }}$ was abolished or irreversibly activated. Single-channel recordings of cationic channel activity in the cell-attached configuration provided evidence for the requirement of second messengers in coupling these receptors to the cationic channels.

The data indicate that in addition to the previously described reduction of $I_{\mathrm{K} \text {, leak }}, I_{\mathrm{M}}$, and $I_{\mathrm{AHP}}$, both $1 S, 3 R-A C P D$ and $\mathrm{MCh}$ activate a nonselective cationic conductance that is clearly revealed upon elevating external $\mathrm{K}^{+}$concentration. This current is mediated by activation of metabotropic

\footnotetext{
Received Nov. 14, 1994; revised Jan. 10, 1994; accepted Jan. 18, 1995

We are indebted to Drs. D. A. Brown, D. Dehanne, and S. M. Thompson for constructive criticism and reading the manuscript. We also thank L. Rietschin, L. Heeb, F. Grogg, E. Hochreutener, and R. Schöb for their excellent technical assistance. This work was supported by the Swiss National Science Foundation (Grant 31-35976.92) and the Prof. Dr. Max Cloëtta Foundation.

Correspondence should be addressed to Nathalie C. Guérineau, Brain Research Institute, August Forel-Strasse 1, University of Zurich, CH-8029 Zurich, Switzerland

Copyright (C) 1995 Society for Neuroscience $0270-6474 / 95 / 154395-13 \$ 05.00 / 0$
}

receptors, although no evidence could be obtained to show an involvement of G-proteins.

[Key words: metabotropic glutamate receptors, muscarinic cholinergic agonist, nonselective cationic conductance, elevated extracellular $K^{\prime}$ concentration, G-proteins, single-channel recordings, hippocampal slice cultures]

Metabotropic glutamate receptors (mGluRs) and muscarinic acetylcholine receptors play a crucial role in the control of excitability in the CNS by modulating the electrical behavior of neurons due to their coupling to numerous membrane ionic conductances (for reviews, see Nicoll et al., 1990; Gerber and Gähwiler, 1994). Electrophysiological studies have demonstrated that activation of postsynaptic mGluRs in hippocampal neurons results in a depolarization associated with an increase in membrane resistance, a reduction of action potential accommodation, and a blockade of the slow calcium-dependent afterhyperpolarization (Stratton et al., 1989, 1990; Baskys et al., 1990; Charpak et al., 1990; Desai and Conn, 1991). Voltage-clamp experiments have revealed that the depolarizing response underlying the stimulation of mGluRs is essentially the consequence of a suppression of at least three $\mathrm{K}^{+}$currents: the voltage-dependent current $I_{\mathrm{M}}$, the slow calcium-dependent afterhyperpolarizing current $I_{\mathrm{AHP}}$, and a voltage-independent leak current $I_{\mathrm{K} \text {,eak }}$ (Charpak et al., 1990; Charpak and Gähwiler, 1991; McCormick and von Krosigk, 1992; Guérineau et al., 1994). These $\mathrm{K}^{+}$currents are similarly diminished in the presence of muscarinic cholinergic agonists (Dodd et al., 1981; Halliwell and Adams, 1982; Lancaster and Adams, 1986; Madison et al., 1987). In addition, previous work has shown that cholinergic atropine-sensitive receptors mediate the activation of nonselective cationic conductances in the hippocampus (Segal, 1982; Benson et al., 1988; Colino and Halliwell, 1993), in neurons of the locus ceruleus (Egan and North, 1985), in neocortical interneurons (McCormick and Prince, 1985, 1986), and in sympathetic ganglion cells (Jones, 1985). To date, it is not clear whether mGluRs gate a similar cationic conductance. Such a conductance may be involved in generating a slow afterdepolarization in response to stimulation of mGluRs in hippocampal, septal, and cortical neurons (Constanti and Libri, 1992; Greene et al., 1992; Zheng and Gallagher, 1992; Caeser et al., 1993) and a depolarization in cerebellar Purkinje cells (Staub et al., 1993).

The purpose of this study was to determine whether activation of muscarinic receptors and mGluRs can induce a cationic current in CA3 pyranidal neurons in ral hippocannpal slice cultures, and, if so, to characterize the second messengers involved. 


\section{Materials and Methods}

Organotypic hippocampal slice cultures were prepared as previously described (Gähwiler, 1981). Briefly, hippocampi were removed under aseptic conditions from 6 -d-old Wistar rats that had been killed by decapitation. Slices ( $400 \mu \mathrm{m}$ thick) were embedded on glass coverslips in a film of clotted chicken plasma, transferred to test tubes containing semisynthetic medium, and then placed in a roller drum (10 revolutions per hr) in an incubator at $36^{\circ} \mathrm{C}$. The culture medium was composed of $50 \%$ Eagle's basal medium, $25 \%$ balanced salt solution containing Hanks' or Earle's salts, and $25 \%$ heat-inactivated horse serum with glucose $33.3 \mathrm{~mm}$. After $15-30 \mathrm{~d}$ in vitro, slices were transferred to a recording chamber attached to the stage of an inverted microscope fitted with differential interference contrast optics and continuously superfused with an extracellular solution at $25^{\circ} \mathrm{C}$ containing (in mM) 137 $\mathrm{NaCl}, 2.7 \mathrm{KCl}, 2.8 \mathrm{CaCl}_{2}, 2 \mathrm{MgCl}_{2}, 11.6 \mathrm{NaHCO}_{3}, 0.4 \mathrm{NaH}_{2} \mathrm{PO}_{4}$ and 5.6 glucose, which was brought to $\mathrm{pH}=7.3$ by bubbling with $\mathrm{CO}_{2}$ When the concentration of $\mathrm{KCl}$ was raised (up to $16 \mathrm{mM}$ ), $\mathrm{NaCl}$ content was correspondingly reduced. In some experiments, $\left[\mathrm{Na}^{+}\right]$, was modified by substituting $N$-methyl-D-glucamine chloride for $\mathrm{NaCl}$ in equimolar amounts. Tetrodotoxin (TTX, $0.5 \mu \mathrm{M}$ ) was added to the superfusing fluid to block propagated electrical activity and to reduce transmitter release.

Electrophysiological experiments were performed on CA3 pyramidal neurons using the patch-clamp technique in the whole-cell configuration or the cell-attached configuration (Hamill et al., 1981). Patch pipettes were pulled to a resistance of $2-5 \mathrm{M} \Omega$ from borosilicate glass $(1.5 \mathrm{~mm}$ outer diameter, $1.17 \mathrm{~mm}$ inner diameter) and filled with the following internal solution for whole-cell patch recordings (in mM): 140 potassium gluconate, $10 \mathrm{KCl}, 2 \mathrm{MgCl}_{2}, 1.1$ EGTA, 5 HEPES, that was titrated to $\mathrm{pH}=7.2$ with $\mathrm{KOH}$. In some experiments, $\mathrm{K}^{+}$ions were replaced by $\mathrm{Cs}^{+}$ions (140 $\mathrm{mM} \mathrm{Cs}^{+}$-gluconate in the patch pipette), and the $\mathrm{pH}$ was adjusted with $\mathrm{CsOH}$. Some cells were loaded with the $\mathrm{Ca}^{2+}$ chelator BAPTA ( $20 \mathrm{~mm}$ ) by passive diffusion from the patch pipette. Membrane currents were recorded under voltage-clamp conditions using a Lis EPC-7 amplifier (List Instruments, Darmstadt, Germany), filtered at 1 $\mathrm{kHz}$ and digitized at $1 \mathrm{kHz}$. Junction potentials were compensated after placing the pipette in the bath. Electrodes were advanced a few microns until they just deformed the membrane of visually identified CA 3 neurons, while maintaining a high positive pressure on the back of the pipctte. High resistance seals ( $>1$ G $\Omega$ ) were obtained by applying negative pressure. The membrane beneath the pipette was then ruptured with strong negative pressure to achieve continuity with the intracellular compartment. Patch-clamp signals were fed into separate channels of an analog to digital converter (TL-1/DMA interface, Axon Instruments, Inc., Foster City, CA), digitized, stored, and analyzed on a PC using pCLAMP software. Voltage pulse generation, data acquisition, and analysis were performed with the same software/hardware system. For single-channel recordings, the patch pipette was filled with the same solution as that used externally, containing $16 \mathrm{mM} \mathrm{K}^{+}$and $0.5 \mu \mathrm{M}$ TTX Unitary currents were amplified with an Axopatch 200A (Digidata 1200 interface, Axon Instruments) and stored on a Panasonic digitizing recorder before off-line analysis using pCLAMP software (version 6.0.1, Axon). Data was sampled at a rate of $5 \mathrm{kHz}$ and filtered with a cut-off frequency of $1.5 \mathrm{kHz}$

Drugs were applied in the bathing fluid for whole-cell recordings and by fast close superfusion for cell-attached recordings. For our fast superfusion system, we have calculated a dilution factor of at least 2.5 and therefore higher agonist concentrations were used to fill the ejection pipette in the cell-attached experiments. Drugs were purchased from the following sources: $1 S, 3 R$-1-aminocyclopentane-1,3-dicarboxylate $(1 S, 3 R$ ACPD), the enantiomer $1 R, 3 S$-ACPD, $(R S)$ - $\alpha$-methyl-4-carboxyphenylglycine (MCPG), 6-cyano-7-nitroquinoxaline-2,3-dione (CNQX), quisqualate, $\mathrm{L}(+)$-2-amino-4-phosphonobutyric acid (L-AP4), and D-2-amino-5-phosphonovalerate (D-APV) from Tocris Neuramin (Bristol, UK); TTX from Sankyo Co., Ltd. (Tokyo, Japan); [bis-(o-aminophenoxy)ethane- $N, N, N^{\prime}, N^{\prime}$-tetraacetic acid] (BAPTA) from Molecular Probes (Eugene, OR); tetraethylammonium chloride (TEA) from Merck (Darmstadt, Germany); guanosine $5^{\prime}-O$-(2-thiodiphosphate) (GDPßS) from Boehringer (Mannheim, Germany); acetyl- $\beta$-methylcholine chloride (methacholine, $\mathrm{MCh})$, L-glutamate, cadmium chloride $\left(\mathrm{Cd}^{2+}\right)$, barium chloride ( $\left.\mathrm{Ba}^{2+}\right), N$-nlethyl-D-glucamine chloride (NMG), atropine, guanosine $5^{\prime}$-triphosphate (GTP), guanosine $5^{\prime}-O$-(3-thiotriphosphate) (GTPyS), and kynurenic acid from Sigma (St. Louis, MO); and pertussis toxin from List Biological Laboratories (Campbell, CA). Pirenzepine was kindly provided by Dr. Karl Thomae (Biberach/Riss, Germany) and
(-)- $\beta$ - $p$-chlorophenyl-GABA (baclofen) was donated by Ciba-Geigy Ltd. (Basle, Switzerland).

Numerical data in the text and figures are presented as the mean \pm SEM. Student's $t$ test was used to compare means when appropriate. Differences between two groups were assessed using the nonparametric Mann-Whitney $U$ test. In some experiments, statistical comparisons between groups were made by using ANOVA and Fisher PLSD as posttests. Differences with $p<0.05$ were considered significant.

\section{Results}

Responses to stimulation of postsynaptic mGluRs and muscarinic receptors were investigated in CA3 pyramidal neurons voltage clamped at a holding potential of $-60 \mathrm{mV}$. Application of $1 S, 3 R$-ACPD, a selective mGluR agonist (Irving et al., 1990) as well as methacholine (MCh), a muscarinic agonist, led to an inward current associated with a decrease in membrane conductance corresponding to a reduction in $I_{\mathrm{K}, \mathrm{cak}}$ (Fig. $1 A, B$, insets), as previously described (Guérineau et al., 1994). Earlier studies have shown that low concentrations of $1 S, 3 R$-ACPD and MCh also reduce the potassium currents $I_{\mathrm{M}}$ and $I_{\mathrm{AHP}}$ (Charpak et al. 1990; Charpak and Gähwiler, 1991). Under conditions of wholecell patch-clamp recording, however, these currents are not significantly involved in these responses (Guérineau et al., 1994)

When the concentration of extracellular potassium was elevated above $5 \mathrm{~mm}, 1 S, 3 R$-ACPD (50 $\mu \mathrm{M}$ for $30 \mathrm{sec})$ and $\mathrm{MCh}$ $(5 \mu \mathrm{M}$ for $30 \mathrm{sec}$ ) induced, in cells voltage clamped at $-60 \mathrm{mV}$, a biphasic response consisting of an inward current followed by a slowly developing outward current (Fig. $1 A, B$ ). To characterize these currents, most experiments were done at $\left[\mathrm{K}^{+}\right]_{0}=16 \mathrm{~mm}$ and $\left[\mathrm{Na}^{+}\right]_{,}=124 \mathrm{~mm}$, conditions under which the inward current was maximal. Application of hyperpolarizing voltage steps $(10 \mathrm{mV}, 800 \mathrm{msec}, 0.1 \mathrm{~Hz})$ revealed that the inward current was associated with an increase in membrane conductance (Fig. $1 A b, B b$, traces 2), whereas the outward current was accompanied by a decrease in membrane conductance (Fig. $1 A b, B b$, traces 3$)$. These changes in membrane conductance are summarized in Table 1.

The induction of this biphasic current by $1 S, 3 R-A C P D$ (or MCh) was mimicked hy application of $\mathrm{r}$-glutamate (250-500 $\mu \mathrm{M}$ for $30 \mathrm{sec})$ in the presence of ionotropic glutamate receptor antagonists CNQX $(20 \mu \mathrm{M})$ and D-APV $(40 \mu \mathrm{M})(n=12$; Fig. $7 B$ ). Because of the selectivity of $1 S, 3 R$-ACPD for mGluRs, all subsequent experiments were performed with this agonist.

\section{Concentration-response curves for $1 \mathrm{~S}, 3 \mathrm{R}-A C P D$-induced inward and outward currents}

Repetitive exposure to agonists resulted in 'rundown' of responses, probably due to the loss of cytosolic components, as commonly observed with whole-cell recordings. For this reason, each neuron was tested with not.more than three different concentrations of agonists. The concentration-response curves for $1 S, 3 R$-ACPD-induced inward and outward currents were well fitted by an asymmetric sigmoidal function, as illustrated in Figure 2. The responses saturated at $50 \mu \mathrm{M} 1 S, 3 R$-ACPD, and exhibited $\mathrm{EC}_{50} \mathrm{~s}$ of $10.8 \mu \mathrm{M}$ and $10.4 \mu \mathrm{M}$ for the inward and outward currents, respectively. In all of the following experiments, we used the saturating concentrations of $50 \mu \mathrm{M}$ for $1 S, 3 R$-ACPD and $5 \mu \mathrm{M}$ for $\mathrm{MCh}$. The inward and the outward currents were regarded as independent processes because no linear correlation between the amplitude of inward and outward currents from cell to cell was found when both parameters were plotted against each other (data not shown).

The first part of this study deals with the voltage dependence, 

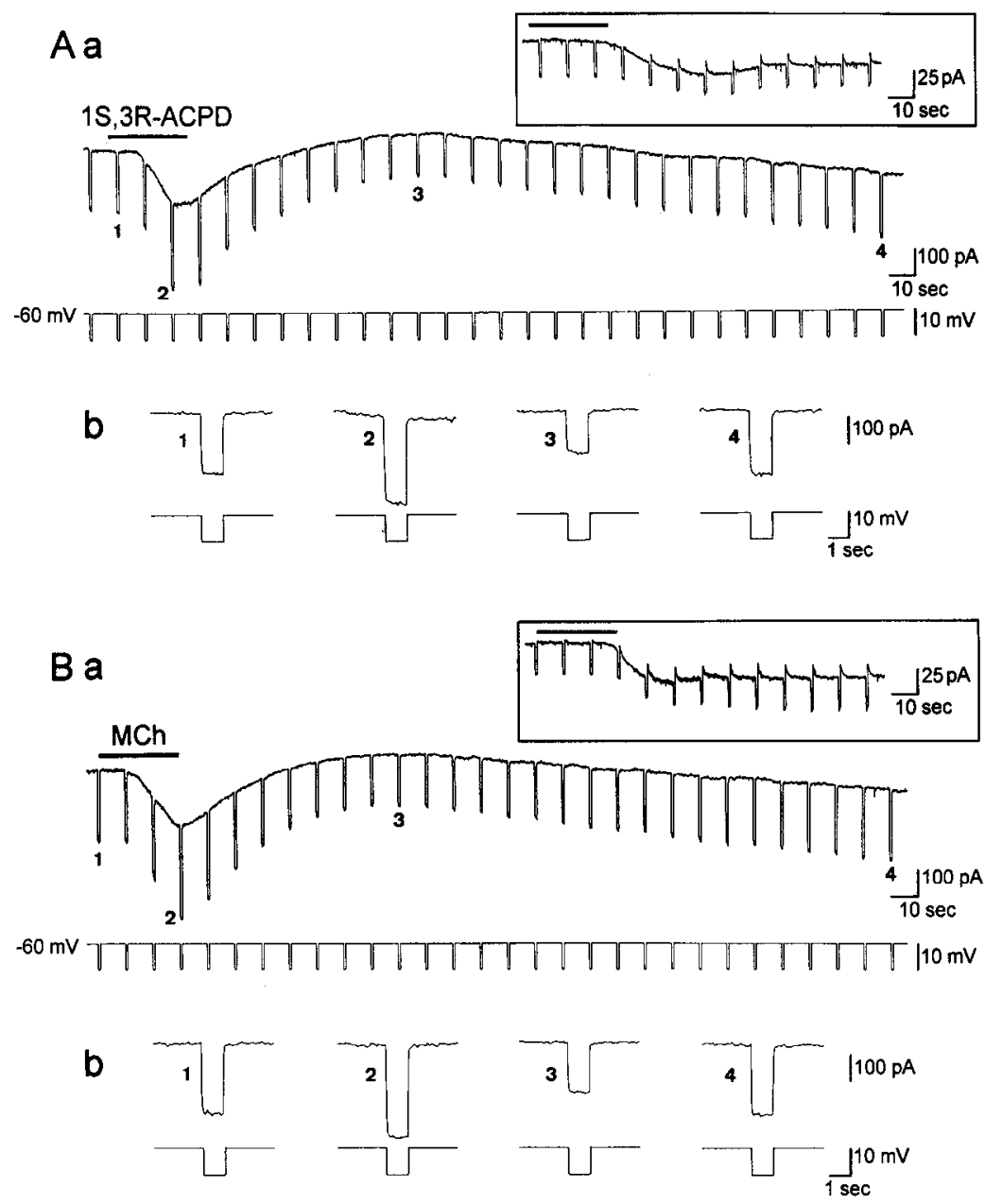

Figure 1. 1S,3R-ACPD and MCh induce a biphasic inward/outward current. A CA3 pyramidal cell was clamped at $-60 \mathrm{mV}$ in $16 \mathrm{~mm}$ extracellular $\mathrm{K}^{+}$solution, and hyperpolarizing voltage pulses were periodically applied to monitor membrane conductance. $1 S, 3 R$-ACPD $(50 \mu \mathrm{M}, A a)$ and MCh $(5 \mu \mathrm{M}, B a)$ each induced an inward current followed by a slowly developing outward current. $A b$ and $B b$, The inward current was associated with an increase in membrane conductance (traces $a 2$ and b2), whereas the outward current was associated with a decrease in membrane conductance (traces $a 3$ and b3). Insets, The two agonistinduced inward currents recorded in $2.7 \mathrm{~mm}$ external $\mathrm{K}^{+}$. These currents were associated with a decrease in membrane conductance. ionic selectivity, and pharmacology of the inward current. The characteristics of the outward current are described in the second part.

\section{$1 \mathrm{~S}, 3 \mathrm{R}-A C P D$ and $M C h$ activate a nonselective cation- permeable conductance}

The reversal potentials of $1 S, 3 R$-ACPD- and $\mathrm{MCh}$-induced inward currents were assessed with a voltage ramp protocol (from -120 to $-50 \mathrm{mV}, 3.5 \mathrm{sec}$ ) before (ramp 1) and during the application of the two agonists (ramp 2 evoked at the peak of the current) (Fig. 3). The currents generated during the voltage ramp were well fitted by a computed linear regression $\left(r^{2}=0.98\right.$ to 1 ), which were then used to determine the potential at which the currents intersect. According to this protocol, the extrapolated reversal potentials were $-9.1 \pm 5.8 \mathrm{mV}(n=18)$ and -12.9

Table 1. Membrane conductance measured before (control) and at the peak of the inward and the outward currents induced by $1 S, 3 R-\Lambda C P D$ and $M C h$

\begin{tabular}{lll} 
& $\begin{array}{ll}1 S, 3 R-\mathrm{ACPD} \\
(50 \mu \mathrm{M})\end{array}$ & $\begin{array}{l}\mathrm{MCh} \\
(5 \mu \mathrm{M})\end{array}$ \\
\hline Control (nS) & $17.4 \pm 1.8$ & $19.4 \pm 2.0$ \\
Inward current $(\mathrm{nS})$ & $25.0 \pm 2.9$ & $28.7 \pm 3.1$ \\
Outward current $(\mathrm{nS})$ & $12.5 \pm 1.8$ & $15.1 \pm 1.5$ \\
Number of cells & 13 & 12 \\
\hline
\end{tabular}

$\pm 8.7 \mathrm{mV}(n=9)$ for $1 S, 3 R-\mathrm{ACPD}$ and $\mathrm{MCh}$, respectively ( $p$ $>0.05$ ). Alternatively, the reversal potential was determined by plotting the current-voltage curve constructed from $1 S, 3 R$ ACPD-induced current measured at three different holding potentials $(-90,-50$, and $-10 \mathrm{mV}$, data not shown, $n=3)$. No appreciable differences $(\leq 5 \mathrm{mV}$ ) were found in the values of the reversal potential calculated by either method. These values are close to the equilibrium potential for monovalent cations, as predicted by the Nernst equation $\left(-1.2 \mathrm{mV}\right.$ at $\left.25^{\circ} \mathrm{C}\right)$ given the experimental [cations] $]_{i}=144.8 \mathrm{mM}$ and [cations] $=152 \mathrm{mM}$. This result is consistent with the involvement of a nonselective cationic conductance.

Subtraction of control currents from those recorded in the presence of agonists yielded the currents activated by $1 S, 3 R$ ACPD or MCh (Fig. 3Ac, Bc) and showed that the conductance underlying this current is voltage independent in the membrane potential range from -120 to $-50 \mathrm{mV}$.

The properties of the $1 S, 3 R$-ACPD- and MCh-induced conductance were studied in more detail by modifying the extracellular monovalent cation concentrations. When $\left[\mathrm{K}^{+}\right]$, was halved ( 16 to $8 \mathrm{mM}$ ), the amplitude of the inward current activated by the two agonists at $-60 \mathrm{mV}$ was reduced by $72 \%$ for $1 S, 3 R$-ACPD $(n=8)$ and $73 \%$ for MCh $(n=6)(p<0.05$, Fig. $4 A, C$ ). Decreasing $\left[\mathrm{Na}^{+}\right]_{o}$ from $124 \mathrm{mM}$ to $70 \mathrm{~mm}$ (Fig. $4 B, C$ ) also led to a decrease in current amplitude (by $34 \%, n=$ 5 and $31 \%, n=6$ for $1 S, 3 R-\mathrm{ACPD}$ and $\mathrm{MCh}$, respectively, $p$ $<0.05$ ). 


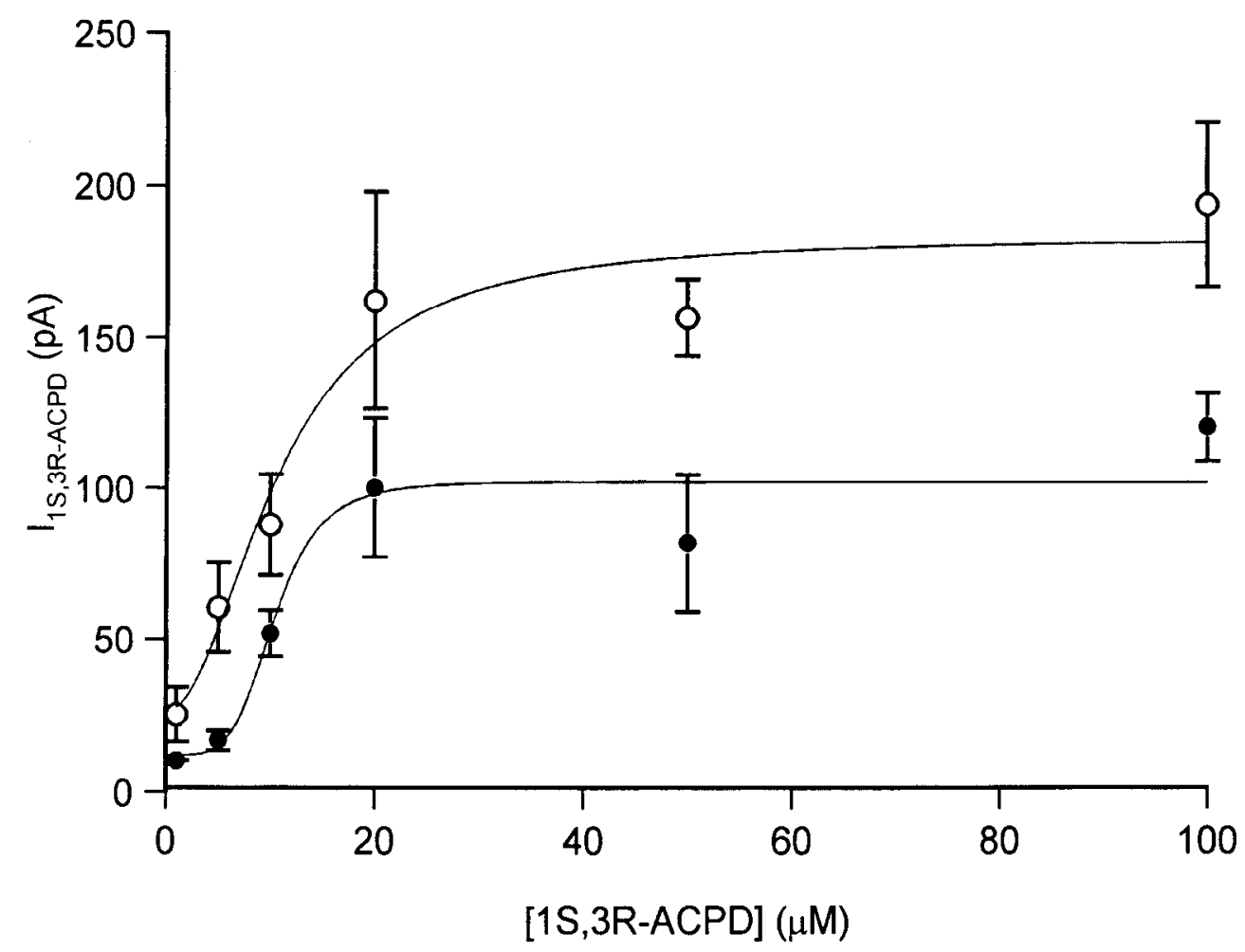

Figure 2. Concentration-response curves for the $1 S, 3 R$-ACPD-induced inward and outward currents. Cells were bathed in 16 mM $\mathrm{K}^{+}$-containing external saline and voltage clamped at $-60 \mathrm{mV}$. Points represent the mean \pm SEM of the $1 S, 3 R$-ACPD-induced inward (open circles) and outward (filled circles) currents measured at the peak of the response. The curves that fitted to the data were derived from an asymmetric sigmoid equation $I=I_{\min }+\left(I_{\max }-I_{\min }\right) /\left\{1+\left(\left[\text { agonist] } / \mathrm{EC}_{50}\right)^{-n}\right\}\right.$ where $I$ is the normalized current amplitude and $n$ is the estimated Hill coefficient $(2.0$ for the inward current and 4.6 for the outward current). The correlation coefficients are 0.98 and 0.96 for $1 S, 3 R$-ACPD-induced inward and outward current, respectively. Five to twenty cells were tested at each agonist concentration.

Moreover, as expected for a response mediated by a change in cationic permeability, decreasing $\left[\mathrm{K}^{+}\right]_{o}$ or $\left[\mathrm{Na}^{+}\right]_{o}$, significantly shifted the reversal potential of $1 S, 3 R$-ACPD- and MCh-induced currents to more negative values compared to those found for $16 \mathrm{mM}\left[\mathrm{K}^{+}\right]_{o}$ and $124 \mathrm{mM}\left[\mathrm{Na}^{+}\right]_{\text {o }}$ (Table 2, $p<0.05$ ).

Outward movement of chloride is unlikely to contribute to this response, since the equilibrium potential for $\mathrm{Cl}^{-}$ions under the present conditions was determined to be $-60.8 \mathrm{mV}$ (at $25^{\circ} \mathrm{C}$ ). Neither the amplitude of the $1 S, 3 R$-ACPD- or MCh-induced responses $(138.5 \pm 27.1 \mathrm{pA}, n=5$ for $1 S, 3 R$-ACPD and $145.4 \pm 24.1 \mathrm{pA}, n=5$ for $\mathrm{MCh}, p>0.05$ ), nor their reversal potentials $(-8.3 \pm 4.4 \mathrm{mV}, n=5$ for $1 S, 3 R$-ACPD and -6.2 $\pm 3.2 \mathrm{mV}, n=5$ for MCh, $p>0.05$ ) were significantly changed by removing extracellular $\mathrm{Ca}^{2+}$. Taken together, these results indicate that the channel underlying the inward current is primarily permeable to the monovalent cations $\mathrm{K}^{+}$and $\mathrm{Na}^{+}$.

The permeability ratio $P_{\mathrm{Na}}: P_{\mathrm{K}}$ of the inward current was calculated using the Goldman-Hodgkin-Katz constant field equation (Goldman, 1943; Hodgkin and Katz, 1949). For $\left[\mathrm{K}^{+}\right]_{o}$ below $5 \mathrm{mM}, P_{\mathrm{Na}}: P_{\mathrm{K}}$ was 0.07 . This value is close to the resting basal permeability for these two ions (Kuffler et al., 1984), and may explain why this current was not detectable in $2.7 \mathrm{mM}\left[\mathrm{K}^{+}\right]_{o}$. When the external $\mathrm{K}^{+}$concentration was raised to $16 \mathrm{mM}$, the ratio appeared to be substantially increased to a $P_{\mathrm{Na}}: P_{\mathrm{K}}$ of 0.76 for $1 S, 3 R$-ACPD- and 1.09 for MCh-induced responses $(n=23$ and 15 for $1 S, 3 R$-ACPD and MCh, respectively).

\section{IS,3R-ACPD and MCh act on the same cationic channels}

As illustrated in the previous figures, application of $1 S, 3 R$ ACPD or MCh produced seemingly identical responses. This raises the possibility that the receptors for $1 S, 3 R$-ACPD and $\mathrm{MCh}$ are coupled to the same channels. To test this hypothesis, the cultures were exposed to a mixture of $1 S, 3 R$-ACPD and MCh (Fig. 5). At low concentrations, concomitant application of the two agonists induced a significant increase in the current amplitude in comparison to that observed in response to only one agonist (Fig. $5 A$, upper traces; $n=13$ ). By contrast, no additive effect was found at saturating agonist concentrations (Fig. 5A, lower traces; $n=7$ ) suggesting that the same channels mediate the response to both $1 S, 3 R$-ACPD and $\mathrm{MCh}$.

\section{Ionic sensitivity of the cationic current}

The effects of divalent cations on the amplitude of current recorded at a holding potential of $-60 \mathrm{mV}$ in $16 \mathrm{mM}\left[\mathrm{K}^{+}\right]_{o}$ were examined. Extracellular exposure to $\mathrm{Ba}^{2+}$ ions $(1 \mathrm{mM})$ decreased the $1 S, 3 R$-ACPD- and MCh-induced currents by 60.4 $\pm 7.5 \%$ and $48.5 \pm 8.4 \%$, respectively $(p<0.05, n=15$; Fig. 6Aa,b). Increasing extracellular $\mathrm{Mg}^{2+}$ from 2 to $10 \mathrm{~mm}$ also reduced the cationic currents induced by $1 S, 3 R$-ACPD and MCh was observed $(82.8 \pm 6.1 \%$ and $86.2 \pm 7.3 \%$, respectively, $p<0.05, n=10$; Fig. $6 B a, b$ ). The responses elicited by the two agonists were also reduced by $95.0 \pm 5.0 \%$ for $1 S, 3 R$-ACPD and $92.4 \pm 6.0 \%$ for MCh $(n=10)$ in $\mathrm{Cd}^{2+}$ containing extracellular saline $(100 \mu \mathrm{M})$. The cationic current did not, however, require an increase in intracellular $\mathrm{Ca}^{2+}$ concentration because loading cells with the $\mathrm{Ca}^{2+}$ chelator BAPTA ( $20 \mathrm{~mm}, 10 \mathrm{~min}$ before agonist exposure) did not modify the current $(p>0.05, n=21)$.

1S,3R-ACPD- and MCh-stimulated inward currents were not 
Aa

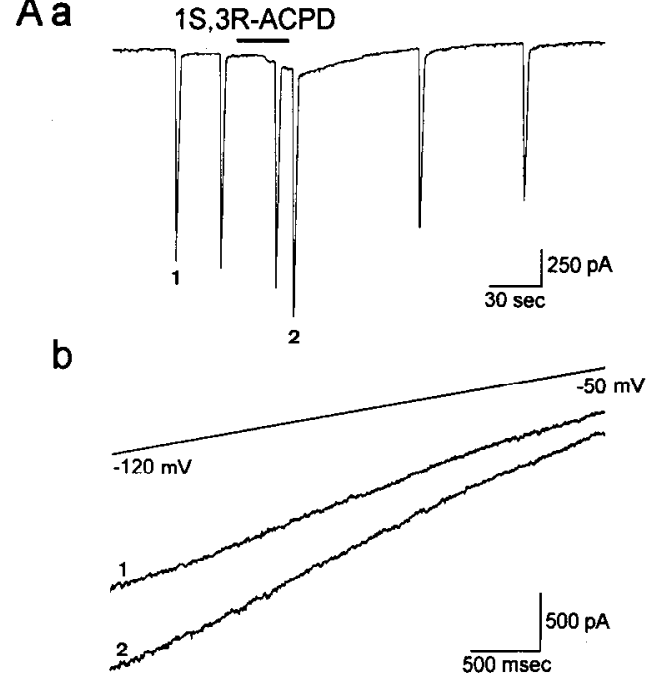

$\mathrm{Ba}$

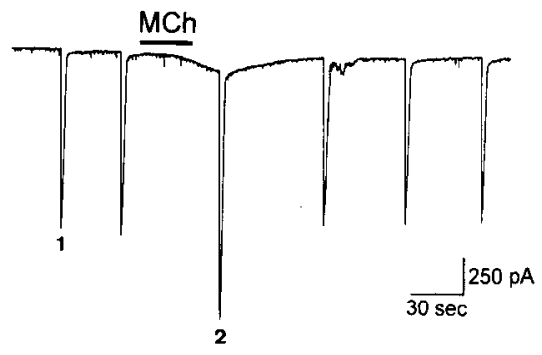

b

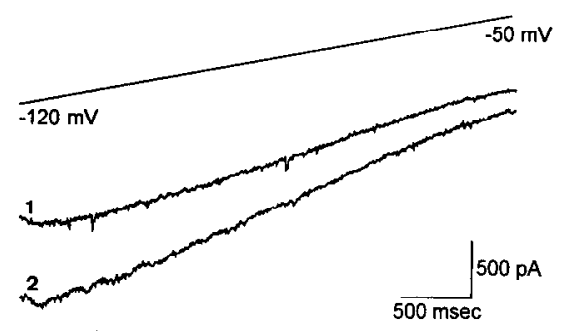

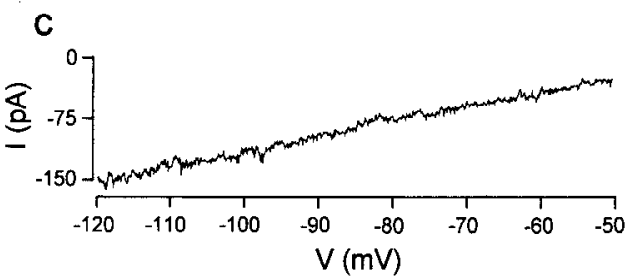

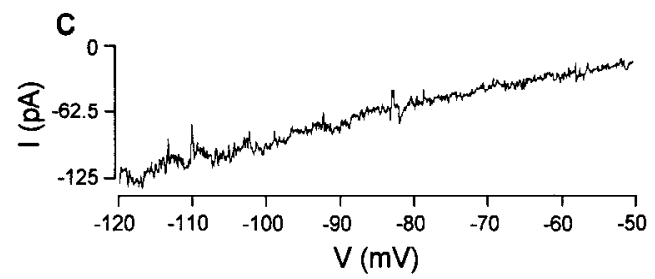

Figure 3. $1 S, 3 R$-ACPD and MCh activate a nonselective, voltage-independent conductance. $A a, b$, and $B a, b$, The reversal potential of the responses to $1 S, 3 R$-ACPD and MCh was assessed by linearly increasing the voltage from -120 to $-50 \mathrm{mV}$ (3.5 sec) before (ramp 1 ) and during (ramp 2) the application of agonists. The extrapolated reversal potential for these currents was close to the equilibrium potential for cations (144.8 mm [cation] $]_{i}$ and $152 \mathrm{~mm}$ [cation] $]_{o}$ ). $A c$ and $B c$, Subtraction of control currents from those in the presence of $1 S, 3 R$-ACPD and MCh revealed that the currents activated by the two agonists varied linearly with membrane potential.

modified in either $\mathrm{Cs}^{+}$-loaded cells $\left(140 \mathrm{mM} \mathrm{Cs}^{+}\right.$-gluconate in the patch pipette, $n=15$ ) or in the presence of extracellular $\mathrm{Cs}^{+}(2 \mathrm{~mm}, n-8$, data not shown, $p>0.05)$. Bath application of tetraethylammonium (TEA, $20 \mathrm{~mm}$ ), however, greatly reduced the responses to both $1 S, 3 R$-ACPD $(73.2 \pm 4.3 \%)$ and MCh $(85.0 \pm 6.1 \%)(p<0.05, n=13)$. Lower TEA concentrations $(1 \mathrm{mM})$ had no effect on the cationic current $(n=5$, data not shown). Pooled data are presented in the histogram (Fig. 6C).

\section{Characterization of glutamatergic and cholinergic receptors} mediating IS,3R-ACPD and MCh-induced cationic current

Although $1 S, 3 R$-ACPD is considered to be a selective agonist at mGluRs (Irving et al., 1990), we examined its response in the presence of the NMDA and AMPA/kainate receptor antagonists D-APV $(40 \mu \mathrm{M})$ and CNQX $(20 \mu \mathrm{M})$ (Watkins and Olverman, 1987) to definitively exclude the involvement of ionotropic glutamate receptors that are also coupled to cation-permeable channels (Fig. 7A). Neither the responses to $1 S, 3 R$-ACPD nor MCh were significantly modified by this treatment $(156.7 \pm 38.1 \mathrm{pA}$ under control conditions, $n=6$ versus $135.8 \pm 30.0 \mathrm{pA}$ in the presence of antagonists, $n=6, p>0.05$ for $1 S, 3 R$-ACPD and $168.8 \pm 26.5 \mathrm{pA}, n=6$ versus $126.3 \pm 37.5 \mathrm{pA}, n=4, p>$ 0.05 for $\mathrm{MCh}$ ). Kynurenic acid (2 mM), a nonselective ionotropic glutamate receptor antagonist, was also without effect $(n$ - 4, data not shown). In the presence of bath-applied MCPG $(1 \mathrm{mM})$, a selective and competitive antagonist at mGluR1 and mGluR2 (Hayashi et al., 1994), the amplitude of the current induced by $1 S, 3 R$-ACPD was significantly reduced (164.3 \pm
$21.1 \mathrm{pA}$ under control conditions, $n=7$ versus $45.0 \pm 10.6$ $\mathrm{pA}$ in MCPG-containing saline, $n=6, p<0.05$ ), while the response to MCh was not modified $(152.0 \pm 28.7 \mathrm{p} \Lambda, n=5$ versus $136.0 \pm 31.9 \mathrm{pA}, n=5, p>0.05) .1 R, 3 S$-ACPD $(100$ $\mu \mathrm{M})$, a potent agonist at phospholipase C-coupled mGluRs in striatum (Manzoni et al., 1992), failed to induce a current ( $n=$ 9, data not shown). Agonist potency profiles were determined to characterize the mGluRs subtypes involved in the cationic current. In the presence of CNQX and D-APV, L-glutamate (500 $\mu \mathrm{M}$ for $30 \mathrm{sec})$ or quisqualate $(0.5 \mu \mathrm{M}$ for $30 \mathrm{sec})$, a potent agonist at mGluR1 and mGluR5 subtypes, were more effective at inducing the inward current than $1 S, 3 R$-ACPD at $50 \mu \mathrm{M}(n$ $=8$ and 10, respectively; Fig. $7 B)$. By contrast, L-AP4 (200 $\mu \mathrm{M}$ for $30 \mathrm{sec}$ ), an agonist at mGluR4, mGluR6 and mGluR7 subtypes (Nakajima et al., 1993; Tanabe et al., 1993; Okamoto et al., 1994) had no effect on membrane current $(n=12)$. This suggests that the activation of the cationic current may be due to the stimulation of mGluR 1 and/or mGluR5 subtypes.

Atropine $(1 \mu \mathrm{M})$ abolished MCh-induced inward current, indicating an action at muscarinic receptors $(n=3$; Fig. 7A). The blockade was not reversible after extensive washing (10-15 $\mathrm{min}$ ). In these three cells, the response to $1 S, 3 R$-ACPD was not altered by atropine. To characterize in more detail the subtype of muscarinic receptors, we tested the effects of bath-applied pirenzepine, an $\mathbf{M}_{1}$ receptor antagonist (North et al., 1985). Within 5 min of superfusion with a high concentration of pirenzepine $(1 \mu \mathrm{M})$, the MCh-induced current was reduced by only $41.5+10.8 \%(n=4$; Fig. $7 A)$, suggesting that the effect of $\mathrm{MCh}$ is probably not due to the activation of $\mathrm{M}_{1}$ receptors. 

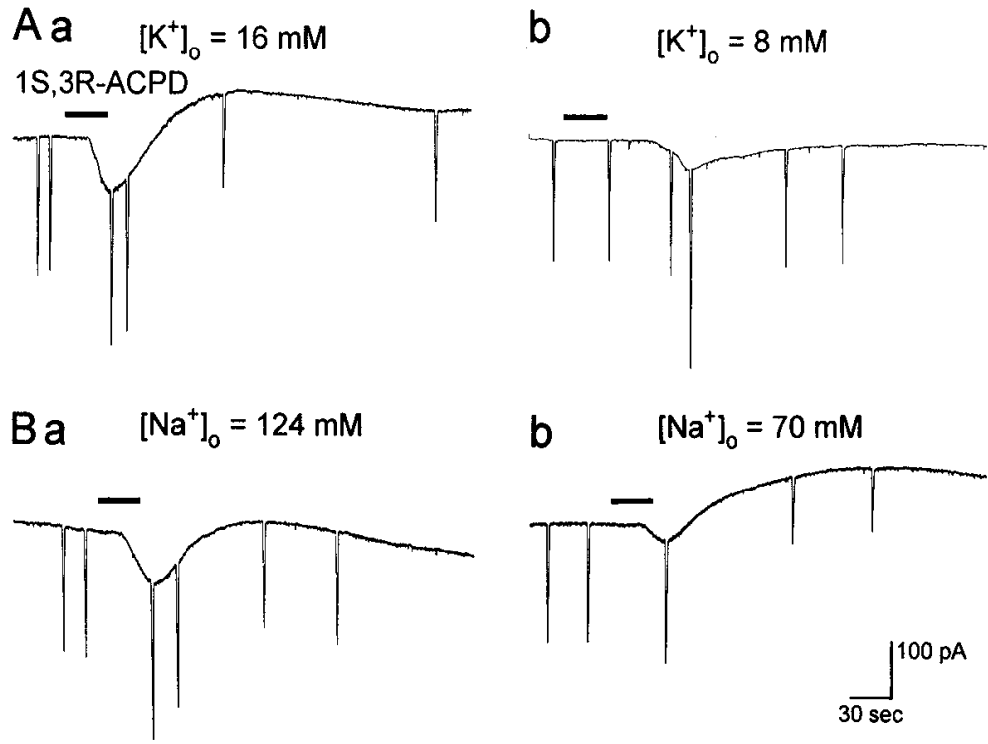

Figure 4. The inward current induced by $1 S, 3 R$-ACPD or MCh is mainly carried by $\mathrm{K}^{+}$and $\mathrm{Na}^{+}$ions. Reducing $\left[\mathrm{K}^{+}\right]_{o}(A a$ and $b)$ or $\left[\mathrm{Na}^{+}\right]_{o}(B a$ and $b)$ led to a decrease in the amplitude of the $1 S, 3 R$-ACPD-induced current in four different cells voltage clamped at $-60 \mathrm{mV}$. $C$, The effects of changing $\left[\mathrm{K}^{+}\right]_{o}$ and $\left[\mathrm{Na}^{+}\right]_{0}$ on the amplitude of the inward current elicited by the two agonists are summarized in the histogram. The number of recorded cells is indicated in parentheses.

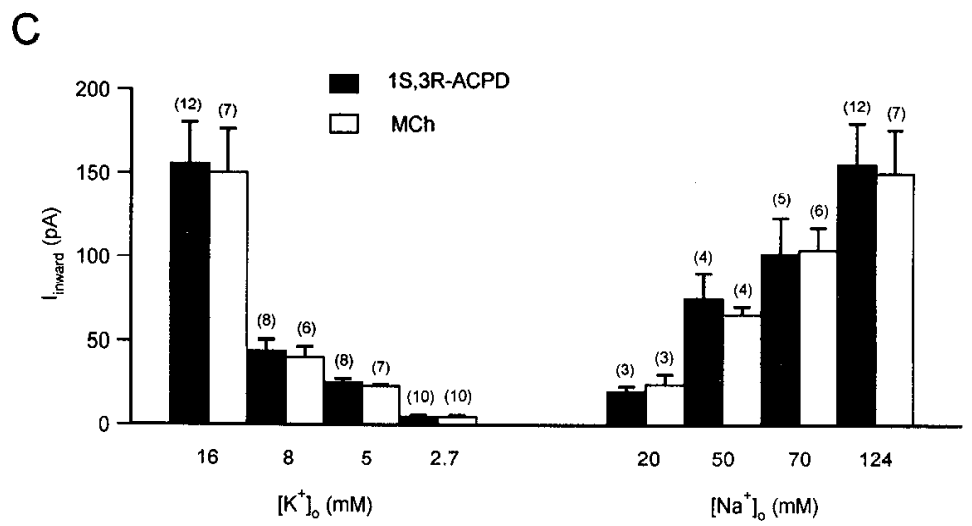

1S,3R-ACPD- and MCh-induced outward current is due to a reduction of a voltage-independent $K^{+}$conductance

In $16 \mathrm{mM} \mathrm{K}^{+}$-containing solution at a holding potcntial of 60 $\mathrm{mV}$, the $1 S, 3 R$-ACPD- and MCh-induced cationic current was followed by a slowly developing, long-lasting outward current

Table 2. Mean reversal potentials for $1 S, 3 R$-ACPD- and MChinduced inward current recorded in three different extracellular $\mathrm{K}^{+}$or $\mathrm{Na}^{+}$consentrations

$$
E_{\text {rev }}(\mathrm{mV})
$$$$
1 S, 3 R-A C P D
$$

$$
E_{\text {rev }}(\mathrm{mV}) \mathrm{MCh}
$$

$\left[\mathrm{K}^{+}\right]_{o}(\mathrm{mM}$

$$
\begin{array}{lrrrr}
124 \mathrm{mM}\left[\mathrm{Na}^{+}\right]_{o} & 5 & -59.7 & \pm 4.1(3) & -60.7 \pm 2.3(4) \\
& 8 & -51.2 \pm 1.8(9) & -51.2 \pm 2.6(12) \\
& 16 & -9.1 \pm 4.4(23) & -3.3 \pm 6.2(15) \\
{\left[\mathrm{Na}^{+}\right]_{o}(\mathrm{mM} ;} & & & & \\
16 \mathrm{mM}\left[\mathrm{K}^{+}\right]_{o} & 50 & -36.0 \pm 2.2(4) & -46.0 \pm 1.1(4) \\
& 70 & -31.5 \pm 1.7(4) & -35.0 \pm 3.1(4) \\
& 124 & -9.1 \pm 4.4(23) & -3.3 \pm 6.2(15)
\end{array}
$$

These reversal potentials were calculated by computed linear regression of the currents generated during a voltage ramp protocol $(-80$ to $-60 \mathrm{mV}, 2 \mathrm{sec})$. The number of cells tested for each cation concentration is indicated in parentheses. that was associated with a decrease in membrane conductance (Fig. 8Aa,Ba). To study the voltage dependence of the currents, voltage jumps of $100 \mathrm{msec}$ duration to test potentials ranging from -120 to $-30 \mathrm{mV}$ were applied to cells before and during application of $1 S, 3 R-\mathrm{ACPD}$ and MCh (Fig. $8 A b, B b$ ). The currents suppressed by the two agonists varied linearly with membrane potential and reversed at $-53.2 \pm 2.7 \mathrm{mV}$ for $1 S, 3 R$ $\operatorname{ACPD}(n=3)$ and $-52.8 \pm 2.8 \mathrm{mV}$ for $\mathrm{MCh}(n=3)$. These values are close to the equilibrium potential for $\mathrm{K}^{+}$, as predicted by the Nernst equation $\left(-57 \mathrm{mV}\right.$ at $25^{\circ} \mathrm{C}$, given the experimental $\left[\mathrm{K}^{+}\right]_{o}=16 \mathrm{~mm}$ and $\left.\left[\mathrm{K}^{+}\right]_{i}=150 \mathrm{~mm}\right)$. Similar values were obtained when the reversal potential was determined using the ramp protocol described for Table $2(-55.1 \pm 1.1 \mathrm{mV}$ for $1 S, 3 R$-ACPD, $n=17$ and $-56.4 \pm 1.5 \mathrm{mV}$ for MCh, $n=11$, data not shown). The ionic selectivity for $\mathbf{K}^{+}$was shown by plotting the reversal potential at three different extracellular $\mathrm{K}^{+}$ concentrations (Fig. $8 A c, B c$ ). Lowering $\left[\mathrm{K}^{+}\right]_{\text {。 }}$ to $2.7 \mathrm{~mm}$ reversed the sign of this current, further suggesting that the response corresponds to the decrease in $I_{K, \text { leak }}$ previously described (Guérineau et al., 1994).

This $\mathrm{K}^{+}$current, which is reduced by $1 S, 3 R-\mathrm{ACPD}$ and $\mathrm{MCh}$, displayed the same sensitivity to receptor antagonists as did the cationic current. MCPG (1 mM) was an effective blocker ( $70 \%)$ of $1 S, 3 R$-ACPD-induced outward current $(25.3 \pm 15.2$ 
A

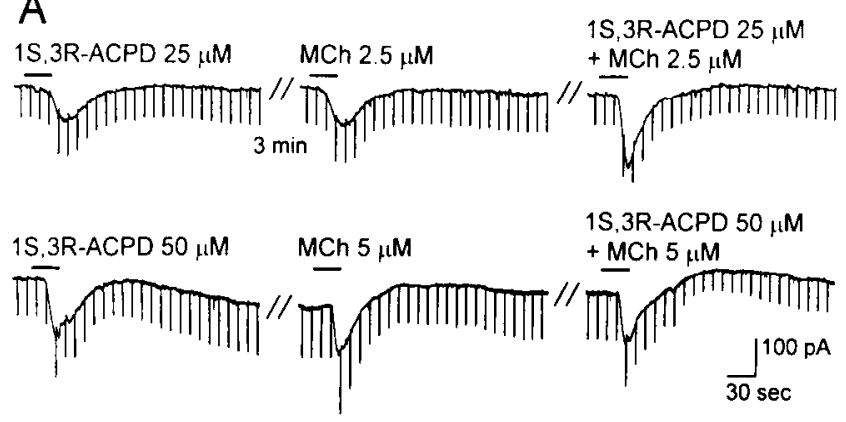

B

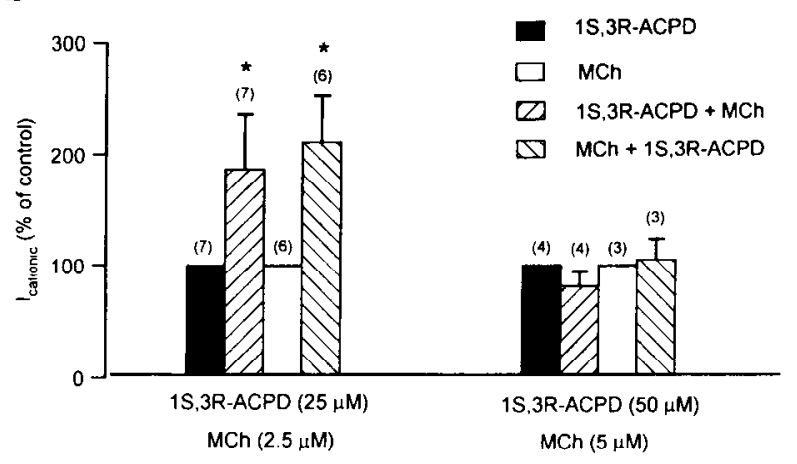

Figure 5. Additive effects of $1 S, 3 R-\mathrm{ACPD}$ and MCh on the cationic conductance. $A$, Cells were held at $60 \mathrm{mV}$ in $16 \mathrm{~mm}$ external $\mathrm{K}^{+}$ solution and exposed to $1 S, 3 R$-ACPD or MCh alone or together. At low concentrations, responses induced by concomitant application of $1 S, 3 R$ $\mathrm{ACPD}$ and MCh were additive (upper traces). At saturating concentrations, the response evoked by combined application of both drugs was not larger than that evoked by either drug alone (lower traces). Pooled data are presented in the histogram $(B)$. The number of tested cells is indicated in parentheses. ${ }^{*}, p<0.05$, as compared to control values.

pA, $n=7$ in the presence of MCPG versus $83.7 \pm 22.5 \mathrm{pA}, n$ $=10$ in control saline, $p<0.05$ ) (data not shown). The response to $\mathrm{MCh}$ was completely antagonized by atropine $(1 \mu \mathrm{M}, n=3)$ but only reduced by $45 \%$ in pirenzepine-containing saline $(1 \mu \mathrm{M}$, 55. $7 \pm 17.3 \mathrm{pA}, n=4$ versus $100.3 \pm 8.9 \mathrm{pA}, n=9, p<$ 0.05 ) (data not shown). In addition, $1 R, 3 S$-ACPD $(100 \mu \mathrm{M})$ was ineffective in inducing a response $(n=9)$.

\section{Role of $G$-proteins}

To establish an involvement of G-proteins in the intracellular transduction pathways stimulated by $1 S, 3 R$-ACPD and $\mathrm{MCh}$, cells were loaded with GTP $\gamma \mathrm{S}(250-500 \mu \mathrm{M}$ for $10 \mathrm{~min})$, a nonhydrolyzable analog of GTP that irreversibly activates G-proteins (Gilman, 1984). The first application of 1S,3R-ACPD activated the inward cationic current followed by the outward $\mathrm{K}^{+}$current, which then remained irreversibly activated (Fig. $9 A$, upper trace), demonstrating the involvement of G-proteins. In contrast, the cationic currents were not affected by GTP $\gamma$ S loading, as shown by successive applications of $1 S, 3 R$-ACPD or MCh in the same cell ( $n=19$; Fig. 9A). The cationic current induced by $1 S, 3 R$-ACPD or $\mathrm{MCh}$ was also not modified in GDP $\beta S$-loaded cells $(250-500 \mu \mathrm{M}$ for $10 \mathrm{~min}$ ), a nonhydrolyzable analog of GDP that prevents G-protein activation (Eckstein et al., 1979). We assumed that GDPßS had effectively diffused into cells if the outward current was decreased by more than
$70 \%$. As summarized in panel $9 B$, the cationic current thus appears to be insensitive to G-protein activation or inactivation, whereas the outward current is respectively increased or abolished by these manipulations. Further evidence for the involvement of different transduction mechanisms mediating the cationic current versus $I_{\text {K.lcak }}$ was obtained by measuring the onset latencies for each response. The onset latency for the inward

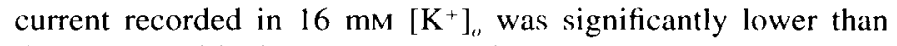
that measured in $2.7 \mathrm{~mm}\left[\mathrm{~K}^{+}\right],(16.5 \pm 0.8 \mathrm{sec}$ versus $28.9 \pm$ $2.5 \mathrm{sec}$ for $1 S, 3 R-\mathrm{ACPD}, n=19$ and 10 respectively, $p<0.05$. and $16.9 \pm 0.9 \mathrm{sec}$ versus $25.3 \pm 1.4 \mathrm{sec}$ for $\mathrm{MCh}, n=21$ and 13 , respectively, $p<0.05$ ) (see also Fig. 1).

In a further attempt to characterize the possible involvement of G-proteins, cells were treated with pertussis toxin $(500 \mathrm{ng} / \mathrm{ml}$ for $48 \mathrm{hr}$ ), which inactivates G-proteins of the Gi/o subtype (Katada and Ui, 1982). Responses to baclofen were now reduced by more than $80 \%$ ( $n=10, p<0.05$ ), as expected for an intracellular transduction pathway known to be mediated by G-proteins sensitive to pertussis toxin (Andrade et al., 1986). In these cells, however, the inward cationic current or the outward $\mathrm{K}^{+}$current induced by $1 S, 3 R$-ACPD or MCh (data not shown, $n=8$ and 10 for $1 S, 3 R$-ACPD and MCh, respectively, $p>$ $0.05)$ were not modified.

\section{Involvement of a second messenger}

Since no evidence could be obtained to show an involvement of G-proteins in mediating the cationic current, this raises the question whether metabotropic, that is, second messenger, pathways underlie this response. To resolve this point, the effects of $1 S, 3 R$ ACPD and MCh on single-channel activity were investigated. A cationic channel was identified in 13 patches out of 136 cells $(9.6 \%)(n=5$ for $1 S, 3 R$-ACPD and 8 for MCh). Figure $10 A$ illustrates a typical recording of this channel. Bath application of $\mathrm{MCh}(100 \mu \mathrm{M})$ outside the recording pipette to a cell voltage clamped at the resting membrane potential triggered, after several seconds latency, inward currents, reflecting ion flux through the open state of the channel. To identify the ionic specificity of this channel, the reversal potential was calculated by plotting the amplitude of the unitary current recorded at different potentials (Fig. 10B). The data were fitted with a linear regression, giving a reversal potential of $+48.9 \mathrm{mV}$ relative to resting membrane potential. Assuming a resting potential of $-50 \mathrm{mV}$, this would correspond to a reversal potential close to $0 \mathrm{mV}$, consistent with the value determined for the whole-cell recordings (Fig. 3, Table 2). The slope conductance for the channel depicted in Figure 10 was $14.3 \mathrm{pS}$. The data for all the recorded channels are summarized in Table 3. In further experiments, unitary recordings from voltage-gated potassium channels were obtained in $16 \mathrm{~mm}$

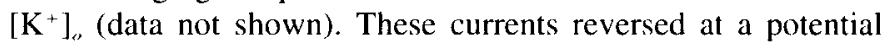
of $-5.8 \pm 4.5 \mathrm{mV}$ relative to resting potential $(n=5)$, corresponding to a membrane potential of $\sim-55 \mathrm{mV}$. This is close to the equilibrium potential of $-57.5 \mathrm{mV}$ for $\mathrm{K}^{+}$ions calculated with the Nernst equation. Thus, these channels could easily be distinguished from cationic channels.

\section{Discussion}

Stimulation of mGluRs and cholinergic muscarinic receptors was shown to activate a nonselective (mainly $\mathrm{K}^{+} / \mathrm{Na}^{+}$) cationic conductance in CA3 hippocampal neurons in the presence of elevated extracellular $\mathrm{K}^{+}$concentration $(\geq 5 \mathrm{~mm}$ ). This initial conductance increase was followed by a second response due to the previously described reduction of $I_{\text {K.leak }}$ (Guérineau et al., 
Figure 6. Ionic sensitivity of the cationic conductance increase. Cells were bathed in $16 \mathrm{mM} \mathrm{K} \mathrm{K}^{+}$-containing external saline and voltage clamped at -60 $m V$. Bath application of divalent cations, $\mathrm{Ba}^{2+}(1 \mathrm{~mm}, A a$ and $b)$ and $\mathrm{Mg}^{2+}$ $(10 \mathrm{~mm}, B a$ and $b)$ reversibly diminished the $1 S, 3 R$-ACPD- and MCh-induced cationic currents in the same cells. C. Summary of the eflects of different divalent cations $\left(\mathrm{Ba}^{2+}, \mathrm{Mg}^{2+}\right.$, $\left.\mathrm{Cd}^{2+} 100 \mu \mathrm{M}\right), \mathrm{K}^{\prime}$ channel inhibitors (TEA $20 \mathrm{~mm}, \mathrm{Cs}^{+} 140 \mathrm{~mm}$ in the patch pipette) and BAPTA (20 mm) on the response induced by the two agonists. The number of tested cells is indicated in parentheses. $*, p<0.05$, as compared to control values.

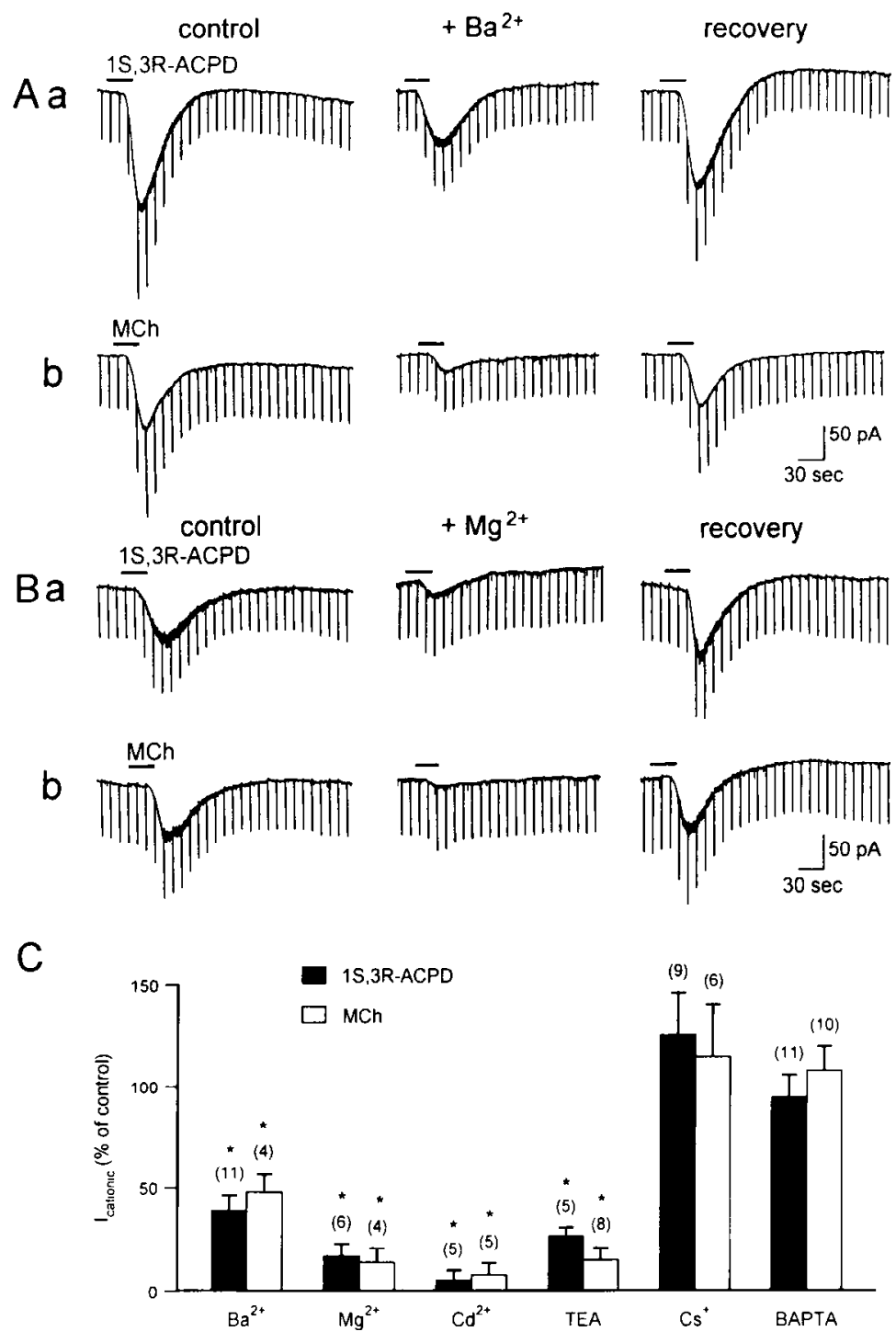

1994). These effects of $1 S, 3 R$-ACPD and MCh are most likely mediated by a direct activation of postsynaptic receptors, since all experiments were performed in the presence of TTX. Furthermore, responses were not altered following 5-15 min of superfusion with $\mathrm{Ca}^{2+}$-depleted solution.

\section{The cationic conductance increase}

The inward current amplitude as well as its reversal potential were modified by changing the extracellular $\mathrm{K}^{+}$and $\mathrm{Na}^{+}$concentrations, consistent with the activation of a nonselective cation channel that is permeable to both $\mathrm{K}^{+}$and $\mathrm{Na}^{+}$ions. Previous studies have reported the presence of a slow afterdepolarization (sADP) in CNS neurons, which is potentiated by mGluR agonists (Greene et al., 1992; Constanti and Libri, 1992; Zheng and Gallagher, 1992; Caeser et al., 1993) and by muscarinic agonists (Schwindt et al., 1988; Caeser et al., 1993). $I_{\mathrm{ADP}}$ has been characterized as a nonspecific cation current that is activated by $\mathrm{Ca}^{2+}$ (Crépel et al., 1994). The cationic current that we observe does not, however, correspond to $I_{\mathrm{ADP}}$ because intracellular BAPTA did not affect the current. Another $\mathrm{Na}^{+} / \mathrm{K}^{+}$current described in hippocampal cells, $I_{Q}$ (or $I_{H}$ ) is activated by hyperpolarization to membrane potentials negative to $\sim-70 \mathrm{mV}$, and is sensitive to extracellular $\mathrm{Cs}^{+}$but insensitive to $\mathrm{Ba}^{2+}$ (Brown and $\mathrm{Di}$ Francesco, 1980; Halliwell and Adams, 1982; Colino and Halliwell, 1993). Unlike $I_{Q}$, however, the cationic current activated by $1 S, 3 R$-ACPD and MCh persists in the presence of extracellular $\mathrm{Cs}^{+}$, and is greatly reduced in the presence of $\mathrm{Ba}^{2+} . A$ similar voltage-insensitive cationic current has been found to contribute to the depolarizing response to muscarine and substance $P$ in the locus ceruleus (Shen and North, 1992a,b; Koyano et al., 1993).

The amplitude of $1 S, 3 R$-ACPD- and MCh-activated cationic current was reversibly decreased by extracellular application of divalent cations. This could be explained by the presence of an external divalent cation-binding site in the pore of the channel (Hillc, 1992). A similar mechanism may account for the observed blockade by TEA of $1 S, 3 R$-ACPD- and MCh-induced currents in hippocampus, and muscarine-induced current in the locus ceruleus (Shen and North, 1992a). However, the cationic current we report here is somewhat different from the current described by Shen and North, in that low TEA concentrations (1 $\mathrm{mM}$ ) did not modify its amplitude. Studies of a muscarinic receptor-aclivated cation channel in guinea-pig ileun indicale that TEA does not modify receptor binding by muscarinic ago- 


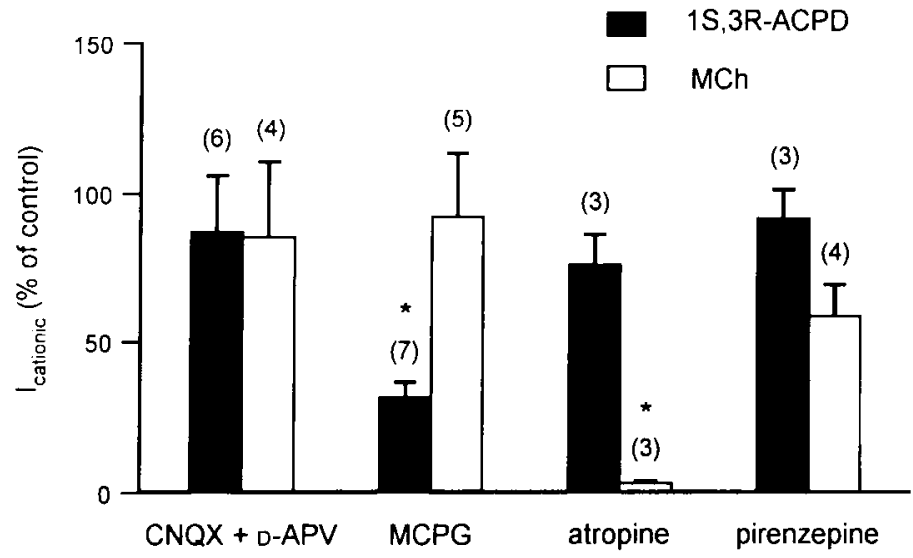

B

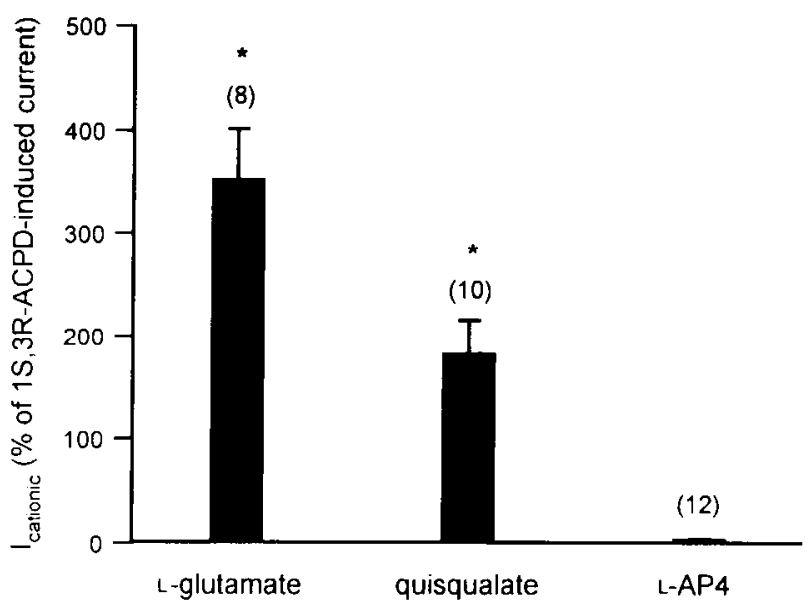

Figure 7. Characterization of receptors mediating the $1 S, 3 R$-ACPD- and MCh-induced cationic currents. $A$, The inward current induced by $1 S, 3 R$ $A C P D$ was reversibly reduced in the presence of extracellular MCPG (1 $\mathrm{mM}$ ), but was unaffected by $\mathrm{CNQX}$ $(20 \mu \mathrm{M})$ and D-APV $(40 \mu \mathrm{M})$. Atropine $(1 \mu \mathrm{M})$ fully antagonized the response to $\mathrm{MCh}$, while pirenzepine at high concentration $(1 \mu \mathrm{M})$ inhibited the cationic current by only $40 \%$. $B$, L- glutamate $(500 \mu \mathrm{M})$ and quisqualate $(0.5 \mu \mathrm{M})$, a potent agonist at mGluR 1 and mGluR5 subtypes, induced the cationic current in the presence of CNQX $(20 \mu \mathrm{M})$ and D-APV $(40 \mu \mathrm{M})$. L-AP4 $(200 \mu \mathrm{M})$, a potent agonist at mGluR4 and mGluR6 subtypes, failed to activate a membrane current. The number of recorded cells is indicated in parentheses. *, $p<$ 0.05 , as compared to control values. nists but acts downstream by occluding the channel (Chen et al,, 1993). Large positively charged molecules such as TEA may be driven into the channel mouth or attracted to a negatively charged binding site located midway down the channel pore and thus interfere with the permeation of cations (Hille, 1992). On the other hand, the amplitude of the currents was not significantly changed by intra- or extracellular $\mathrm{Cs}^{+}$, indicating that the channel is permeable to small cations such as $\mathrm{Cs}^{+}$. In contrast to the cationic conductance described in the cortex (Andrade, 1993) and in arca CAl of the hippocampus (Colino and Halliwell, 1993), the response we observed was not $\mathrm{Ca}^{2+}$ dependent.

The permeability ratio $P_{\mathrm{Na}}: P_{\mathrm{K}}$ was calculated to be 0.07 for $\left[\mathrm{K}^{+}\right]_{a} \leq 5 \mathrm{~mm}$ but was greatly increased upon raising $\left[\mathrm{K}^{+}\right]_{\text {, }}$ to $16 \mathrm{~mm}$. This behavior is not compatible with a channel model based on the assumption of independent membrane fluxes of ions. Rather, an interaction between the two cationic species may be occurring within the channel to account for the nonlinearity of the relationship between extracellular $\mathrm{K}^{+}$concentration and channel permeability (Hille, 1992).

\section{Characterization of receptors}

The action of $1 S, 3 R$-ACPD is clearly mediated by mGluRs. Specific antagonists at ionotropic glutamate receptors did not alter the inward current activated by $1 S, 3 R$-ACPD, whereas MCPG, a selective and competitive antagonist at mGluR1 and mGluR2
(Hayashi et al., 1994), was an effective blocker of the $1 S, 3 R$ ACPD-induced inward current but not of the MCh-induced response. L-AP4, the most potent known agonist at mGluR4, mGluR6, and mGluR7 (Nakajima et al., 1993; Tanabe et al., 1993; Okamoto et al., 1994), was without effect, whereas quisqualate, a potent agonist at mGluR 1 and mGluR5, induced responses comparable but greater than those observed with $1 S .3 R$ ACPD. Based on these pharmacological data, and on in situ hybridization studies that demonstrate that hippocampal CA3 pyramidal cells cxpress mainly mGluRl and mGluR5 (Abc ct al., 1992; Shigemoto et al., 1992), the mGluRs mediating the observed responses are likely to correspond to these subtypes.

Pirenzepine $(1 \mu \mathrm{M})$, which has a $K_{D}$ of $10 \mathrm{nM}$ at the $\mathrm{M}_{1}$ subtype of the muscarinic receptor (North et al., 1985), inhibited only $40 \%$ of the cationic current. Thus, the MCh-induced current is probably mediated by receptors other than the $M_{1}$ subtype. Previous studies describing the activation of a cationic conductance by cholinergic agonists have reported the involvement of the $\mathbf{M}_{2}$ subtype muscarinic receptor in locus ceruleus neurons (Egan and North, 1985) and in hippocampal CAl cells (Colino and Halliwell, 1993).

Pharmacologically indistinguishable mGluRs and muscarinic receptors gate both the increase in cation conductance and the decrease in $\mathrm{K}^{+}$conductance. Both conductances were sensitive to the same pharmacological agents, that is, blockade by MCPG 
Aa

Figure 8 . A reduction of $I_{\text {K.leak }}$ by $1 S, 3 R-\mathrm{ACPD}$ and MCh is responsible for the outward current. $A a$ and $B a$, $1 S, 3 R$-ACPD- and MCh-induced typical biphasic responses in a cell voltage clamped at $-60 \mathrm{mV}$ in $16 \mathrm{~mm}\left[\mathrm{~K}^{+}\right]_{,}$. $A b$ and $B b$. Steady-state $I / V$ curves for the two agonist-evoked outward currents were determined by applying voltage steps $(100 \mathrm{msec})$ to test potentials ranging from -120 to $-30 \mathrm{mV}$ in the same cell. Subtraction of control currents from those during $1 S, 3 R$ ACPD and MCh revealed that the currents suppressed by the two agonists varied linearly with membrane potential and that the outward current reversed at a potential close to the equilibrium potential for $\mathrm{K}^{+}$ions. $A c$ and $B c$. Plots of pooled data for the reversal potential at three different $\left[\mathrm{K}^{+}\right]_{\ldots}$. The solid line represents the relationship of reversal potential to $\left[\mathrm{K}^{+}\right]_{\text {, }}$ as predicted by the Nernst equation. The number of tested cells is indicated in parentheses.

\section{a}

1S,3R-ACPD

b
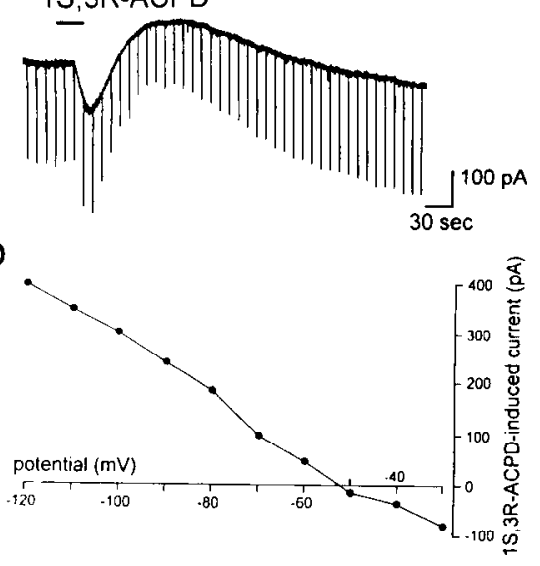

C

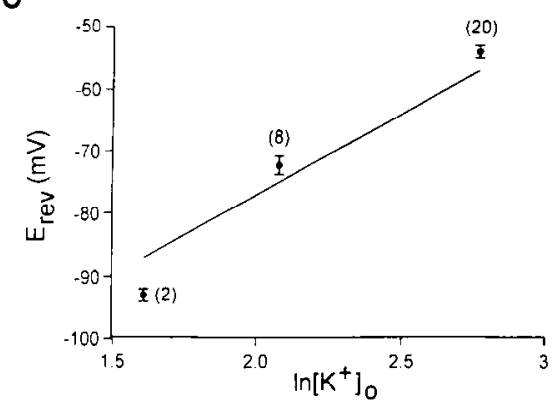

$\mathrm{Ba}$

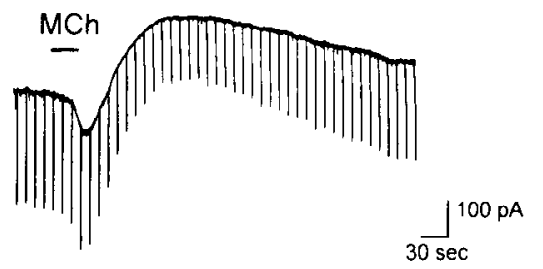

b

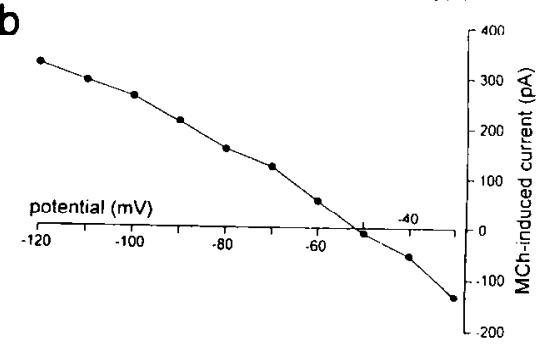

C

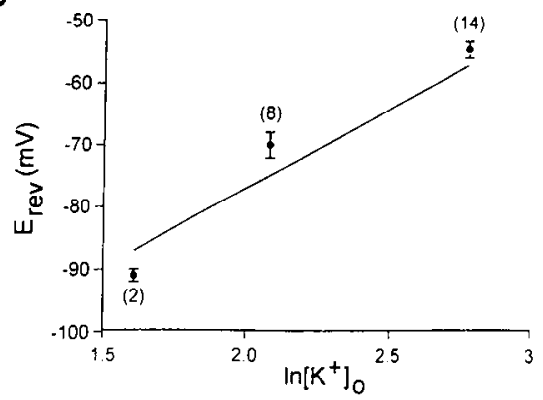

for $1 S, 3 R$-ACPD-induced currents and sensitivity to atropine but not to pirenzepine for $\mathrm{MCh}$-activated current. This raises the possibility that the two currents result from activation of the same glutamatergic and cholinergic muscarinic receptors, each receptor coupling to two different types of ion channels. The fact that the $\mathrm{EC}_{50}$ s for the two currents are in the same range $(\sim 10 \mu \mathrm{M}$ for $1 S, 3 R$-ACPD) argues in favor of this hypothesis. The availability of receptor subtype-specific agonists and antagonists will permit the resolution of this point in the future.

\section{The delayed decrease in $\mathrm{I}_{\text {K.leak }}$}

In addition to activation of a nonselective cationic conductance, IS,3R-ACPD and MCh caused a reduction of a $\mathrm{K}^{+}$conductance. According to its electrophysiological and pharmacological characteristics, that is, time course, reversal potential, voltage independence, blockade by the selective mGluRs antagonist MCPG, and similar sensitivity to intracellular loading with guanine nucleotides, this response corresponds to the previously characterized decrease in $I_{\text {K.leik }}$ (Guérineau et al., 1994).

\section{Mechanisms of receptor-effector coupling}

Our results suggest that mGluRs and muscarinic receptors gate a common cationic conductance. The inward currents induced by $1 S, 3 R$-ACPD and MCh displayed a similar time course, reversal potential, and current-voltage relationship. Furthermore, the responses induced by both agonists were additive at submaximal concentrations but mutually occlusive at saturating concentrations. Pretreatment with pertussis toxin did not modify either response and, surprisingly, neither did intracellular loading with GDPBS or GIP $\gamma \mathrm{S}$. In the same cells, these guanine nucleotide analogs markedly altered the outward current corresponding to the reduction in a previously characterized leak $\mathrm{K}^{+}$current (Guérineau et al., 1994). Furthermore, the shorter onset latency observed for the cationic current versus $I_{\text {K.k:ak }}$ is consistent with the activation of two separate intracellular transduction pathways. We conclude that either the cationic current is activated by a novel glutamate receptor not coupled to G-proteins, that guanine nucleotides introduced into cells do not have access to the receptor/G-protein complexes, perhaps due their localization on distal dendrites, or that a novel as yet uncharacterized molecule couples these receptors to the cationic channels. We have previously observed that responses to stimulation of $\mathrm{GABA}_{\mathrm{B}}$ receptors, which are localized on hippocampal pyramidal cell dendrites (Newberry and Nicoll, 1985), are sensitive to GDPßS and GTP $\gamma \mathrm{S}$, indicating effective diffusion from the pipette into at least part of the dendritic tree (Guérineau et al., 1994). Although our single-channel experiments show that cationic channels can be found on the cell body, we cannot at present rule out a localization of the receptors on distal dendrites.

Is "metabotropic" an appropriate label for a non-G-proteincoupled receptor? To answer this question, one must first rule out the involvement of an ionotropic receptor. This was the rationale for our single-channel experiments. The fact that re sponses were observed in cell-attached patches when agonists were applied outside the recording pipette implicates diffusible second messengers in coupling these receptors to the cationic channels (Hille, 1994). Furthermore, the long latency between agonist application and channel activation suggests that secondmessenger production occurs at a distance from the channels. Therefore, although the receptor does not appear to be G-protein-coupled, the term metabotropic is, nonetheless, justified. Similar currents that appear to be G-protein-independent have been described for a number of receptor systems (Olesen et al., 1988; Koyano et al., 1993; Twitchell and Rane, 1993; White et al., 1993) including mGluRs (Kehoe, 1994). 
A

GTP $\gamma$ S-loaded cells
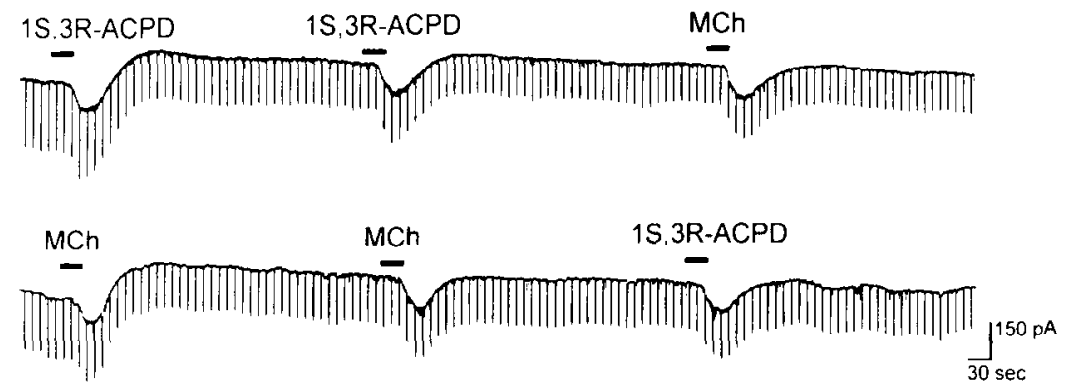

Figure 9. Role of G-proteins in the mediation of $1 S, 3 R$-ACPD- and $\mathrm{MCh}$ induced currents. $A$, In GTP $\gamma$ S-loaded cells $(250 \mu \mathrm{M}$ for $10 \mathrm{~min})$, the first application of $1 S, 3 R$-ACPD (upper trace) or MCh (lower rrace) induced the inward current followed by the prolonged activation of the outward current. Subsequent exposures to $1 S, 3 R$-ACPD or $\mathrm{MCh}$, in the same cells, activated only the inward current. $B$, Histograms summarizing the effects of GTP $(100 \mu \mathrm{M})$ GTP $\gamma S$ (250-500 $\mu \mathrm{M})$ and GDPßS $(500 \mu \mathrm{M})$ on the amplitude of both inward cationic and outward $\mathrm{K}^{+}$currents induced by $1 S, 3 R$-ACPD and $\mathrm{MCh}$ The cationic current remained insensitive to these manipulations, while the inhibition of $\mathrm{K}^{+}$current was enhanced by GTP or GTP $\gamma$ S, and was strongly reduced by GDP $\beta S$ loading. The number of recorded cells is indicated in $p a$ rentheses. ${ }^{*}, p<0.05$, as compared to control values.

A

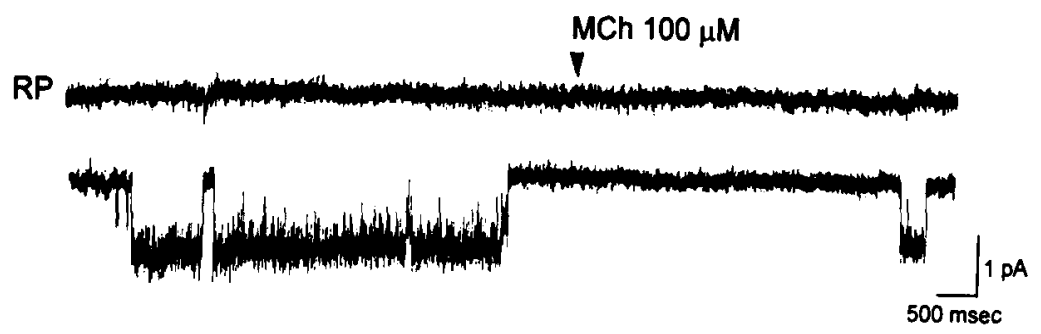

B
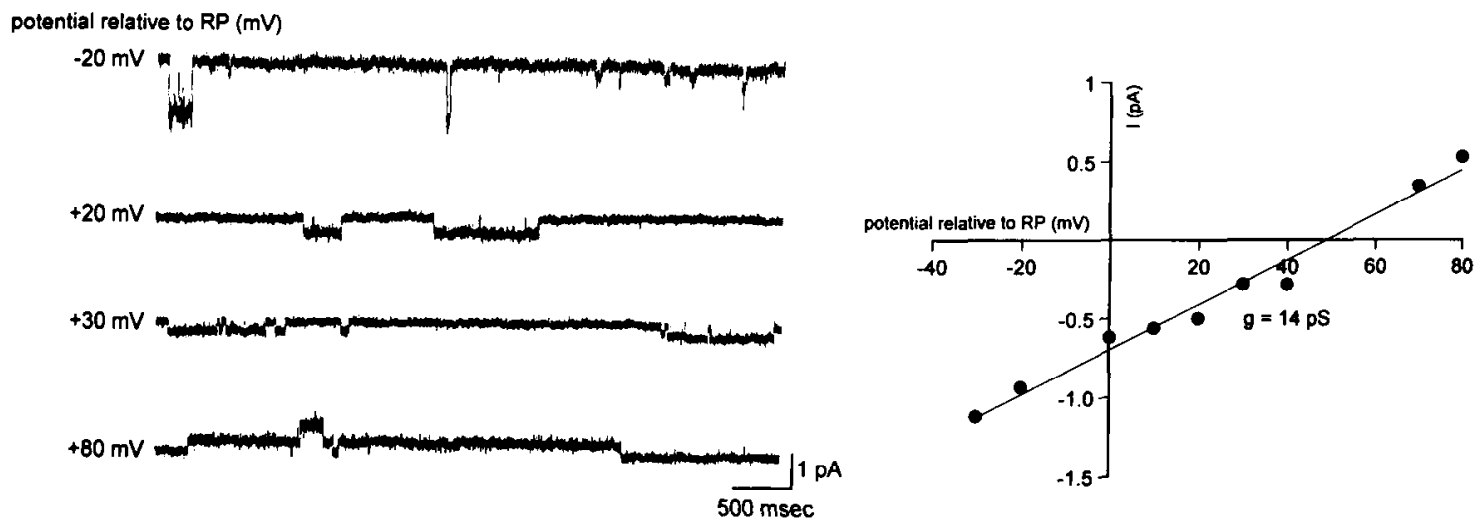

Figure 10. Single-channel recording of cationic channel activity. Unitary currents were recorded in the cell-attached configuration at resting potential (RP) with a patch pipette filled with extracellular saline containing $16 \mathrm{mM} \mathrm{K} \mathrm{K}^{+}$and $0.5 \mu \mathrm{M}$ TTX. A, Bath application of MCh (100 $\mu \mathrm{M}$ ) outside the pipette triggered inward currents reflecting ion flux through the open state of the channel. $B$, The reversal potential of the unitary current was assessed by plotting the amplitude of the current measured at different pipette potentials. The data were fitted by a linear regression $\left(r^{2}=\right.$ 0.98 ), giving a reversal potential close to $+50 \mathrm{mV}$ relative to $\mathrm{RP}$ and a slope conductance of $14.3 \mathrm{pS}$. 
Table 3. Characteristics of cationic channels opened by prolonged bath-application of $1 S, 3 R$-ACPD or MCh

\begin{tabular}{lcc} 
& $\begin{array}{l}1 S, 3 R-\mathrm{ACPD} \\
(500 \mu \mathrm{M})\end{array}$ & $\begin{array}{l}\text { MCh } \\
(100 \mu \mathrm{M})\end{array}$ \\
\hline Latency (sec) & $38.2 \pm 10.7(5)$ & $21.8 \pm 8.3(6)$ \\
Amplitude at RP (pA) & $0.97 \pm 0.04(5)$ & $0.82 \pm 0.07(8)$ \\
Unitary conductance $(\mathrm{pS})$ & $17.3 \pm 4.2(3)$ & $17.5 \pm 0.9(6)$ \\
$E_{\text {re relative to RP }(\mathrm{mV})}+42.9 \pm 4.9(3)$ & $+57.4 \pm 3.7(6)$
\end{tabular}

Currents were recorded in the cell-attached configuration with a patch pipette filled with an external saline containing $16 \mathrm{~mm} \mathrm{~K}$ and $0.5 \mu \mathrm{M}$ TTX. For each parameter, no statistical difference between $1 S, 3 R$-ACPD- or MCh-induced unitary cationic currents was found. RP denotes resting potential. The number of recorded cells is indicated in parentheses.

\section{Physiological implications}

These results extend previous observations on the remarkable similarities in the responses to stimulation of mGluRs and muscarinic acetylcholine receptors (Charpak et al., 1990; Miller, 1991). Activation of these receptors modulates several potassium currents, including $I_{\mathrm{M}}, I_{\mathrm{AHP}}$, and $I_{\mathrm{K} \text {. cak }}$, calcium currents, and the calcium-dependent cationic current underlying $I_{\mathrm{ADP}}$ (see $\mathrm{Ni}$ coll et al., 1990; Miller, 1991; Gerber and Gähwiler, 1994). The fact that two separate neurotransmitter systems activate receptors mediating slow modulatory responses in parallel attests to the physiological importance of the underlying currents. For example, activation of either of these receptor systems has been shown to facilitate the induction of long-term potentiation (Blitzer et al., 1990; Katsuki et al., 1992; Bashir et al., 1993). The glutamatergic system may be primarily involved for local modulation while cholinergic pathways may represent a mechanism for communication between separate brain areas (e.g., septohippocampal).

The cationic current was only observed when the extracellular $\mathrm{K}^{+}$concentration was raised above $5 \mathrm{~mm}$. Although the resting extracellular $\mathrm{K}^{+}$concentration in brain lies between 2.8 to 3.4 $\mathrm{mm}$, increases to as much as $10-15 \mathrm{~mm}$ are seen during epileptic seizures, after repetitive stimulation or following exposure to excitatory amino acids, whereas concentration as high as 100 $\mathrm{mm}$ have been observed during ischemia (see Walz and Hertz, 1983).

Activation of a nonspecific $\mathrm{Na}^{+} / \mathrm{K}^{+}$conductance leads to a membrane depolarization that could contribute to the excitatory effects of glutamate and acetylcholine (McComick and Prince, 1986; Benson et al., 1988). Since the cationic conductance becomes more prominent upon accumulation of extracellular $\mathrm{K}^{+}$ ions, it may participate in positive feedback mechanisms important in physiological processes such as synaptic plasticity or in pathological situations such as epilepsy.

\section{References}

Abe $T$, Sugihara $H$, Nawa $H$, Shigemoto R, Mizuno $N$, Nakanishi $S$ (1992) Molecular characterization of a novel metabotropic glutamate receptor mGluR5 coupled to inositol phosphate/ $\mathrm{Ca}^{2+}$ signal transduction. J Biol Chem 267:13361-13368.

Andrade R (1993) Muscarinic receptors induce the appearance of a calcium-activated cation conductance in rat cortex. Soc Neurosci Abstr 19:117.11.

Andrade R, Malenka RC, Nicoll RA (1986) A G-protein couples serotonin and $\mathrm{GABA}_{\mathrm{B}}$ receptors to the same channel in the hippocampus. Science 324:1261-1265.

Bashir ZI, Bortolotto ZA, Davies CH, Beretta N, Irving AJ, Seal AJ, Henley JM, Jane DE, Watkins JC, Collingridge GL (1993) Induction of LTP in the hippocampus needs synaptic activation of glutamate metabotropic receptors. Nature 363:347-350.

Baskys A, Bernstein NK, Barolet AW, Carlen PL (1990) NMDA and quisqualate reduce a $\mathrm{Ca}$ dependent $\mathrm{K}^{+}$current by a protein kinasemediated mechanism. Neurosci Lett 112:76-81.

Benson DM, Blitzer RD, Landau EM (1988) An analysis of the depolarization produced in guinea-pig hippocampus by cholinergic receptor stimulation. J Physiol (Lond) 404:479-496.

Blitzer RD, Gil O, Landau EM (1990) Cholinergic stimulation enhances long-term potentiation in the $\mathrm{CA} 1$ region of rat hippocampus. Neurosci Lett 119:207-210

Brown H, DiFrancesco D (1980) Voltage-clamp investigations of membrane currents underlying pace-maker activity in rabbit sino-atrial node. J Physiol (Lond) 308:331-351.

Caeser M, Brown DA, Gähwiler BH, Knöpfel T (1993) Characterization of a calcium-dependent current generating a slow afterdepolarization of CA3 pyramidal cells in rat hippocampal slice cultures. Eur J Neurosci 5:560-569.

Charpak S, Gähwiler BH (1991) Glutamate mediates a slow synaptic response in hippocampal slice cultures. Proc R Soc Lond [Biol] 243: $22 \mathrm{l}-226$.

Charpak S, Gähwiler BH, Do KQ, Knöpfel T (1990) Potassium conductances in hippocampal neurons blocked by excitatory amino-acid transmitters. Nature 347:765-767.

Chen S, Inoue R, Ito Y (1993) Pharmacological characterization of muscarinic receptor-activated cation channcls in guinea-pig ileum. $\mathrm{Br}$ J Pharmacol 109:793-801.

Colino A, Halliwell JV (1993) Carbachol potentiates Q current and activates a calcium-dependent non-specific conductance in rat hippocampus in vitro. Eur J Neurosci 5:1198-1209.

Constanti A, Libri V (1992) Trans-ACPD induces a slow post-stimulus inward tail current $\left(I_{A D P}\right)$ in guinea-pig olfactory cortex neurones in vitro. Eur J Pharmacol 214:105-106.

Crépel V, Aniksztejn L, Ben-Ari Y, Hammond C (1994) Glutamate metabotropic receptors increase a $\mathrm{Ca}^{24}$-activated nonspecific cationic current in CAI hippocampal neurons. J Neurophysiol 72:1561-1569.

Desai MA, Conn PJ (1991) Excitatory effects of ACPD receptor activation in the hippocampus are mediated by direct effects on pyramidal cells and blockade of synaptic inhibition. J Neurophysiol 66: $40-52$.

Dodd J, Dingledine R, Kelly JS (1981) The excitatory action of acetylcholine on hippocampal neurons of the guinea-pig and rat maintained in vitro. Brain Res 207:109-127.

Eckstein F, Cassel D, Levkovitz H, Lowe M, Selinger Z (1979) Guanosine 5'-O-(2-thiodiphosphate): an inhibitor of adenylate cyclase stimulated by guanine nucleotide and fluoride ions. J Biol Chem 254: 9829-9834.

Egan TM, North RA (1985) Acetylcholine acts on $m_{2}$-muscarinic receptors to excite rat locus coeruleus neurones. $\mathrm{Br} \mathrm{J}$ Pharmacol 85 : $733-735$

Gähwiler BH (1981) Organotypic monolayer cultures of nervous tissue. J Neurosci Methods 4:329-342.

Gerber U, Gähwiler BH (1994) Modulation of ionic currents by metabotropic glutamate receptors in the CNS. In: The metabotropic glutamate receptors (Conn PJ, Patel J, eds), pp 125-146. Totowa, NJ: Humana.

Gilman AG (1984) G-Proteins and dual control of adenylate cyclase. Cell 36:577-579.

Goldman DE (1943) Potential, inpedance, and rectification in mentbrane. J Gen Physiol 27:37-60.

Greene C, Schwindt P, Crill W (1992) Metabotropic receptor mediated after-depolarization in neocortical neurons. Eur J Pharmacol (Mol Pharmacol) 226:279-280.

Guérineau NC, Gähwiler BH. Gerber U (1994) Reduction of resting $\mathrm{K}^{+}$current by metabotropic glutamate and muscarinic receptors in rat CA3 cells: mediation by G-proteins. J Physiol (Lond) 474:27-33.

Halliwell JV, Adams PR (1982) Voltage clamp analysis of muscarinic excitation in hippocampal neurons. Brain Res 250:71-92.

Hamill OP, Marty A, Neher E, Sakmann B, Sigworth FJ (1981) Improved patch-clamp techniques for high-resolution current recording from cells and cell-free membrane patches. Pfluegers Arch 391:85100.

Hayashi Y, Sekiyama N, Nakanishi S, Jane DE, Sunter DC, Birse EF, Udvarhelyi PM, Watkins JC (1994) Analysis of agonist and antag- 
onist activities of phenylglycine derivatives for different cloned metabotropic glutamate receptor subtypes. J Neurosci 14:3370-3377.

Hille B (1992) Ionic channels of excitable membranes. Sunderland, MA: Sinauer.

Hille B (1994) Modulation of ion-channel function by G-protein-coupled receptors. Trends Neurosci 17:531-536.

Hodgkin AL, Katz. B (1949) The effect of sodium ions on the electrical activity of the giant axon of the squid. J Physiol (Lond) 108:33-77.

Irving AJ, Schofield JG, Watkins JC, Sunter DC, Collingridge GL (1990) $1 S, 3 R$-ACPD stimulates and L-AP3 blocks $\mathrm{Ca}^{2+}$ mobilization in rat cerebellar neurons. Eur J Pharmacol 186:363-365.

Iones SW (1985) Muscarinic and peptidergic excitation of bulfrog sympathetic neurones. J Physiol (Lond) 366:6.3-87.

Katada T, Ui M (1982) Direct modulation of the membrane adenylate cyclase system by islet-activating protein due to ADP-ribosylation of a membrane protein. Proc Natl Acad Sci USA 79:3129-3133.

Katsuki H, Saito H, Satoh M (1992) The involvement of muscarinic, $\beta$-idrenergic and metabotropic glutamate receptors in long-term potentiation in the fimbria-CA3 pathway of the hippocampus. Neurosci Lett 142:249-252.

Kehoe J (1994) Glutamate activated a $\mathrm{K}^{+}$conductance increase in Aplysia neurons that appears to be independent of G-proteins. Neuron 13:691-702.

Koyano K, Velimirovic BM, Grigg JJ, Nakajima S, Nakajima Y (1993) Two signal transduction mechanisms of substance $P$-induced depolarization in locus coeruleus neurons. Eur J Neurosci 5:1189-1197.

Kuffler SW, Nicholls JG, Martin AR (1984) From neuron to brain. Sunderland, MA: Sinauer.

Lancaster B, Adams PR (1986) Calcium-dependent current generating the afterhyperpolarization of hippocampal neurons. J Neurophysiol 55:1268-1282.

Madison DV. Lancaster B, Nicoll RA (1987) Voltage-clamp analysis of cholinergic action in the hippocampus. J Neurosci 7:733-741.

Manzoni O, Prezeau L, Rassendren FA, Sladeczek F, Curry K, Bockaert $J$ (1992) Both enantiomers of I-aminocyclopentyl-1,3-dicarboxylate are full agonists of metabo-tropic glutamate receptors coupled to phospholipase C. Mol Pharmacol 42:322-327.

McCormick DA, Prince DA (1985) Two types of muscarinic response to acetylcholine in mammalian cortical neurons. Proc Natl Acad Sci ISA 82:6344-6348.

McCormick DA. Prince DA (1986) Mechanisms of action of acetylcholine in the guinea-pig cerebral cortex in vitro. J Physiol (Lond) 375: 169-194.

McCormick DA, von Krosigk M (1992) Corticothalamic activation modulates thalamic firing through glutamate "metabotropic" receptors. Proc Natl Acad Sci USA 89:2774-2778.

Miller RJ (1991) Metabotropic excitatory amino acid receptors reveals their true colors. Trends Pharmacol Sci 146:365-367.

Nakajima $Y$, Iwakabe H, Akazawa C, Nawa H, Shigemoto R, Mizuno $\mathrm{N}$, Nakanishi $\mathrm{S}$ (1993) Molecular characterization of a novel retinal metabotropic glutamate receptor mGluR6 with a high agonist selectivity for L-2-amino-4-phosphonobutyrate. J Biol Chem 268:11868 11873.

Newberry NR. Nicoll RA (1985) Comparison of the action of baclofen with $\gamma$-aminobutyric acid on rat hippocampal pyramidal cells in vitro. J Physiol (Lond) 360:161-185.
Nicoll RA, Malenka RC, Kauer JA (1990) Functional comparison of neurotransmitter receptor subtypes in mammalian central nervous system. Physiol Rev 70:513-565.

North RA, Slack BE, Surprenant A (1985) Muscarinic $M_{1}$ and $M_{2}$ receptors mediate depolarization and presynaptic inhibition in guineapig enteric nervous system. J Physiol (Lond) 368:435-452.

Okamoto N, Hori S, Akazawa C, Hayashi Y, Shigemoto R, Mizuno N, Nakanishi S (1994) Molecular characterization of a new metabotropic glutamate receptor mGluR7 coupled to inhibitory cyclic AMP signal transduction. J Biol Chem 269:123I-1236.

Olesen SP, Davies PF, Clapham DE (1988) Muscarinic-activated K current in bovine aortic endothelial cells. Circ Res 62:1059-1064.

Schwindt PC, Spain WJ, Foehring RC, Chubb MC, Crill WE (1988) Slow conductances in neurons from cat sensorimotor cortex in vitro and their role in slow excitability changes. J Neurophysiol 59:450467.

Segal M (1982) Multiple actions of acetylcholine at a muscarinic receptor studied in the rat hippocampal slice. Brain Res 246:77-87.

Shen KZ, North RA (1992a) Muscarine increases cation conductance and decreases potassium conductance in rat locus coeruleus neurones. J Physiol (Lond) 455:471-485.

Shen KZ, North RA (1992b) Substance P opens cation channels and closes potassium channels in rat locus coeruleus neurons. Neuroscience 50:345-353.

Shigemoto R, Nakanishi S, Mizuno N (1992) Distribution of the mRNA for a metabotropic glutamate receptor (mGluR 1 ) in the central nervous system: an in situ hybridization study in adult and developing rat. J Comp Neurol 322:121-135.

Staub C, Vranesic I, Knöpfel T (1992) Response to metabotropic glutamate receptor activation in cerebellar Purkinje cells: induction of an inward current. Eur J Neurosci 4:832-839.

Stratton KR, Worley PF; Baraban JM (1989) Excitation of hippocampal neurons by stimulation of glutamate Qp receptors. Eur J Pharmacol 173:235-237.

Stratton KR, Worley PF, Baraban JM (1990) Pharmacological characterization of phosphoinositide-linked glutamate receptor excitation of hippocampal neurons. Eur J Pharmacol 186:357-361.

Tanabe Y, Nomura A, Masu M, Shigemoto R, Mizumo N, Nakanishi S (1993) Signal transduction, pharmacological properties, and expression patterns of two rat metabotropic glutamate receptors, mGluR3 and mGluR4. J Neurosci 13:1372-1378.

Twitchell W, Rane S (1993) A $\mu$-opioid receptor modulates BK current in chromaffin cells by a GTP-independent mechanism. Soc Neurosci Abstr 19:294.11

Walz W, Hertz L (1983) Functional interactions between neurons and astrocytes. II. Potassium homeostasis at the cellular level. Prog Neurobiol 20:133-183.

Watkins JC, Olverman HJ (1987) Agonists and antagonists for excitatory amino acid receptors. Trends Neurosci 10:265-272.

White RE, Lee AB, Shcherbatko AD, Lincoln TM. Schonbrunn A, Armstrong DL (1993) Potassium channel stimulation by natriuretic peptides through cGMP-dependent dephosphorylation. Nature 361: 263-266.

Zheng F. Gallagher JP (1992) Metabotropic glutamate receptor agonists potentiate a slow afterdepolarization in CNS neurons. Neuroreport $3: 622-624$. 